\title{
Israel: Submerged Prehistoric Sites and Settlements on the Mediterranean Coastline- the Current State of the Art
}

\author{
Ehud Galili, Baruch Rosen, Mina Weinstein Evron, \\ Israel Hershkovitz, Vered Eshed, \\ and Liora Kolska Horwitz
}

\begin{abstract}
Inundated archaeological sites dating from the Middle Palaeolithic to the Pottery Neolithic periods have been exposed off the Mediterranean coast of Israel, mainly the northern Carmel coast. The bulk of the sites represents in situ Neolithic settlements dating from the tenth to the seventh millennia BP, including the Pre-Pottery Neolithic site of
\end{abstract}

\section{E. Galili $(\bowtie)$}

Zinman Institute of Archaeology, University of Haifa, Haifa, Israel

Israel Antiquities Authority, Haifa, Israel

e-mail: galilish@netvision.net.il

B. Rosen

Independent researcher, Atlit, Israel

e-mail: resenbar@netvision.net.il

\section{W. Evron}

Zinman Institute of Archaeology, University of Haifa, Haifa, Israel

e-mail: evron@research.haifa.ac.il

I. Hershkovitz

Department of Anatomy and Anthropology, Faculty of Medicine, Tel-Aviv University, Tel Aviv, Israel

e-mail: anatom2@tauex.tau.ac.il

\section{Eshed}

Israel Antiquities Authority, Jerusalem, Israel veshed@gmail.com

\section{K. Horwitz}

National Natural History Collections, Faculty of Life

Science, Berman Building, E. Safra Campus,

The Hebrew University, Jerusalem, Israel

lix1000@gmail.com
Atlit-Yam and the Pottery Neolithic sites of Kfar Samir, Kfar Galim, Tel Hreiz and NeveYam. These are some of the best-preserved underwater settlements in the world with excellent preservation of human and animal remains, plant materials used as food and animal fodder, basketry, wood used in building construction and for making bowls and a wide range of flint, bone and ground-stone artefacts. The sites include rectangular stone dwellings, the earliest known stone-built water wells in the world, megalithic structures of probable ritual significance, numerous human burials, many in stone-lined graves or cists, and reveal details of village layout including a separation between domestic and graveyard areas. The human remains provide pathological evidence for the earliest known case of tuberculosis and for malarial infection. These settlements are the earliest known examples of the typical Mediterranean fishing village, with a subsistence economy based on crop cultivation, domestic animals, some hunting of wild animals, a significant emphasis on marine fishing and the earliest known evidence for the production of olive oil. This combination of resources contributed to the establishment of year-round sedentary, Mediterranean fishing villages. These features owe their preservation and discovery to the location of the settlements on the shoreline. Rising sea level eventually forced their abandonment and sealed 
the remains in anaerobic conditions under a protective cover of marine sand, until recent disturbance by storms and sand-mining exposed parts of the submerged ancient land surface to archaeological discovery.

\section{Keywords}

Atlit-Yam · Underwater settlements .

Palaeocoastlines $\cdot$ Sea level $\cdot$ Domestication .

Pre-Pottery Neolithic $\cdot$ Pottery Neolithic

\subsection{Introduction}

Israel has a long tradition of underwater archaeology and has produced some of the best preserved and best studied underwater Stone Age settlements in the world, with a total of 23 sites of which 19 are in situ settlements or sectors of settlements (Table 23.1). They are concentrated on the Mediterranean littoral in northern Israel and are mostly of Neolithic date lying at depths rang-

Table 23.1 Chronological chart showing main archaeological periods and cultures of the southern Levant, with particular reference to the underwater sites of the Carmel and Galilee coasts from 10,000 to 6000 cal BP

\begin{tabular}{|c|c|c|c|}
\hline Cal years BP & Archaeological Period & Archaeological Culture & Submerged Sites/Settlements \\
\hline $6800-5600$ & \multicolumn{2}{|l|}{ Chalcolithic } & \\
\hline \multirow[t]{12}{*}{$7700-6800$} & \multirow{12}{*}{$\begin{array}{l}\text { Late Pottery Neolithic/Early } \\
\text { Chalcolithic }\end{array}$} & \multirow[t]{12}{*}{ Wadi Rabah } & Kfar-Samir (S, Centre \& N) \\
\hline & & & Hishuley Carmel (S \& N) \\
\hline & & & Kfar-Galim (S \& N) \\
\hline & & & Nahal Galim \\
\hline & & & Hahoterim \\
\hline & & & Tel Hreiz (S \& N) \\
\hline & & & Megadim \\
\hline & & & Atlit north bay \\
\hline & & & Neve-Yam south \\
\hline & & & Neve-Yam west \\
\hline & & & Neve-Yam Temanun Island \\
\hline & & & Habonim \\
\hline Pre-7700 & Prehistoric & & Carmel Head \\
\hline $7800-7700$ & \multirow[t]{2}{*}{ Early Pottery Neolithic } & Lodian & \multirow[t]{2}{*}{ Neve-Yam north } \\
\hline $8400-7800$ & & Yarmukian & \\
\hline $9000-8400$ & \multirow[t]{3}{*}{ Pre-Pottery Neolithic } & $\begin{array}{l}\text { Pre-Pottery Neolithic } \\
\text { C }\end{array}$ & \multirow[t]{3}{*}{ Atlit-Yam } \\
\hline $10,500-9000$ & & $\begin{array}{l}\text { Pre-Pottery Neolithic } \\
\text { B }\end{array}$ & \\
\hline $11,500-10,500$ & & $\begin{array}{l}\text { Pre-Pottery Neolithic } \\
\text { A }\end{array}$ & \\
\hline $14,500-11,500$ & \multirow[t]{2}{*}{ Epipalaeolithic } & Natufian & Nahal Beit Haemeq \\
\hline $22,000-14,500$ & & Kebaran & Caesarea south anchorage \\
\hline $47,000-22,000$ & \multicolumn{2}{|l|}{ Upper Palaeolithic } & \\
\hline $160,000-47,000$ & Middle Palaeolithic & $\begin{array}{l}\text { Middle-Late } \\
\text { Mousterian }\end{array}$ & Kfar Samir centre \\
\hline $250,000-160,000$ & \multicolumn{2}{|l|}{ Middle Palaeolithic } & \\
\hline $\begin{array}{l}1,500,000- \\
250,000\end{array}$ & \multicolumn{2}{|l|}{ Lower Palaeolithic } & \\
\hline
\end{tabular}

Modified after Gopher (2012) and Bar-Yosef and Garfinkel (2008)

Chronological boundaries in some cases are approximate or time transgressive across different sites and regions. The Wadi Rabah culture is considered as Late Pottery Neolithic by some scholars and Early Chalcolithic by others. The Palaeolithic sites are unstratified finds, Neve-Yam Temanun is a human burial, and Neve-Yam west is a stone tumulus. All the other sites are settlements. The date of the Carmel Head (also referred to as Carmel Nose) stone cairns is uncertain, although based on their depth and distance from the shoreline they may be Pottery Neolithic or earlier 
ing from the modern intertidal zone down to $-12 \mathrm{~m}$, the earliest in situ sites occurring at greatest depth and furthest offshore. Submerged sites from earlier periods are rare and comprise lithic scatters of Middle and Upper Palaeolithic material. In this chapter we summarise the palaeogeographical context of the material and the geological factors contributing to its survival and discovery, describe the underwater sites and the finds recovered from them and assess their significance in relation to sea-level rise and the archaeology of the wider region.

\subsection{Palaeogeographical Context and Preservation Conditions}

The Mediterranean coast of Israel is c. $195 \mathrm{~km}$ long, oriented north-south in northern Israel and north-east to south-west in southern Israel. It is slightly curved with mostly sandy beaches in the south, coastal erosional cliffs in the centre and rocky and sandy areas in the north on the Carmel and Galilee coasts. The offshore shelf that would have been exposed at a sea-level regression of $-120 \mathrm{~m}$ is about $40 \mathrm{~km}$ wide in the south, tapering to $10 \mathrm{~km}$ in northern Israel and narrowing further to a few kilometres along the coast of Lebanon and Syria (Fig. 23.1; see Galili et al. 2017a for further details).

The area of new land exposed at low sea levels would have offered a significant and relatively productive increment of land, with fertile coastal plains and rivers. Geomorphological features identified on the submerged shelf that provide clues to the palaeoenvironmental and landscape context of human activity are 'kurkar' ridges (formed of calcareous-cemented, aeolian, quartz sandstone), palaeosols, river channels and variable sediment cover dominated by sand but with intermittent areas of clay or sandy clay. The submerged kurkar ridges represent consolidated sand dunes that formed along palaeocoastlines during lower sea-level still stands. The sand content is high in carbonate resulting in rapid cementation to form a hard, aeolianite rock (see Ammerman, this volume for other examples). These ridges run parallel to the coast and when on dry land can impede drainage, creating wetland environments with clay sediments in the lowlands behind and between them. In some locations, stream channels cut through the ridges, creating narrow valleys or canyons. Sandy-loam palaeosols often red in colour (known locally as 'hamra') developed on the kurkar ridges, and often between them (in central Israel) when the shelf was a subaerial landscape. Submerged prehistoric remains recovered off the Carmel coast are embedded in the upper layer of palaeosol clay sediments of terrestrial origin, which date to the Upper Pleistocene and Early Holocene, 14,563$9534 \mathrm{cal}$ BP (Sneh and Klein 1984). The water retentive properties of the clay may have been a valuable environmental feature for the inhabitants of the ancient landscape. They also offer the best conditions for preserving organic artefacts after the settlements had been inundated by sealevel rise.

Tidal range on this coast is minimal, $0.5 \mathrm{~m}$ or less, but wind fetch is large, extending for up to $2000 \mathrm{~km}$ to the west, generating large waveswells during westerlies and waves up to $10 \mathrm{~m}$ in height. Though much of the wave energy is dissipated by the relatively shallow slope of the continental shelf and the submerged kurkar ridges, storm disturbance is a significant factor. Despite their potentially destructive effects, storms can actually enhance the discovery of submerged features by periodically removing areas of sand cover and exposing the underlying palaeo-landsurface, as discussed below.

In this region, the main source of sediments accumulated on the sea floor is the large volume of quartz sand discharged by the River Nile and carried by longshore currents along the coastline of the Sinai and the Levant as far north as Haifa Bay in northern Israel (Zviely et al. 2007). Most of this is deposited as sand along the inner shelf, with sediments containing a higher proportion of fluvial clay originating from the local coastal streams deposited further offshore. The sand cover plays an important role in protecting the underlying archaeological deposits and features of the original palaeo-land-surface. The best conditions for discovering such inundated sites are near the shore along the Carmel coast, where the 


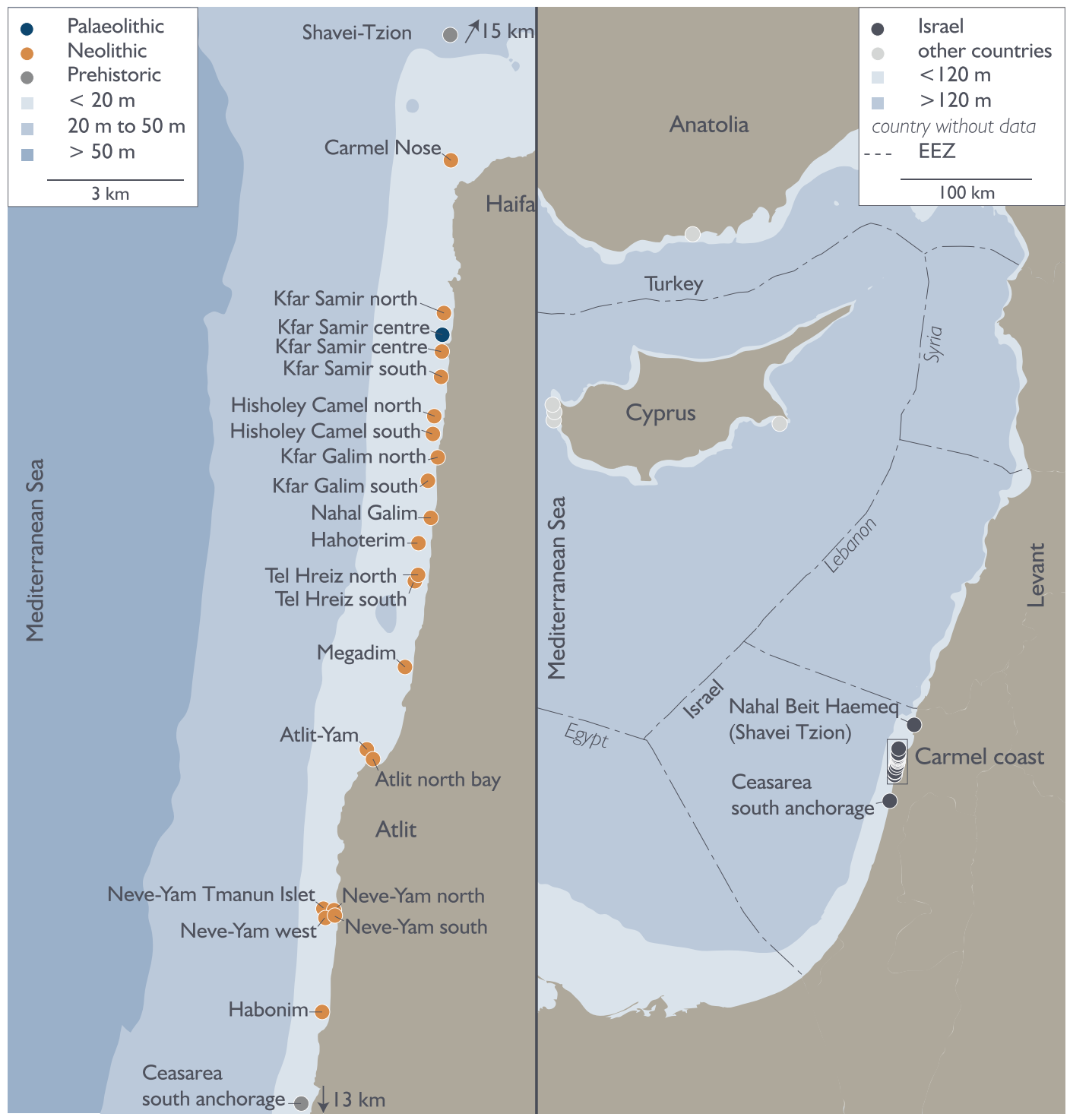

Fig. 23.1 Location map showing distribution of underwater sites. Site information from the SPLASHCOS Viewer http://splashcos-viewer.eu. Drawing by Moritz Mennenga

sand cover is thick enough $(1-3 \mathrm{~m})$ to provide protective cover, but thin enough that periodic storms or other disturbances can remove it to expose archaeological features on the underlying land surface. On the Galilee coast further to the north, the continental shelf is narrower and rocky, and the sediment cover thinner, with poorer conditions for site preservation and discovery, while to the south, the sand cover is thicker with fewer opportunities for the exposure of the underlying palaeo-land-surface.

It is this factor of protective sand cover subject to periodic disturbance, more than any other, that accounts for the preservation and exposure of sites on the sea bottom. Coupled with a long tradition of monitoring the shoreline and the underwater environment for signs of disturbance after storms by members of the public, sports divers 
and professional archaeologists, this has resulted in the discovery of a concentration of underwater settlements in northern Israel (Wreschner 1977a, b; Galili et al. 1988). In recent decades, human activities and especially sand mining have accelerated the removal of sand cover. This has enhanced the potential for discovery of archaeological sites but also increased the threats to their long-term preservation.

\subsection{Archaeological Context}

The southern Levant has a long history of human occupation, and the region is widely considered to have provided one of the primary corridors for human dispersal and expansion out of Africa both for archaic humans after c. 1.4 Ma and for anatomical moderns c. $200 \mathrm{ka}$ (Enzel and Bar-Yosef 2017; Hershkovitz et al. 2018). The earliest sites on, or close to, the Carmel coast are the open-air site of Evron Quarry dated to c. $800 \mathrm{ka}$ (Ron et al. 2003) and the later Mount Carmel caves with long sequences of Lower, Middle and Upper Palaeolithic as well as Epipalaeolithic material extending back to at least $500 \mathrm{ka}$ (Garrod and Bate 1937; Shea 2003; Weinstein-Evron 2015). The role of coastlines and the coastal plain in these early periods is unclear, and the earliest reliable evidence is flint artefacts found directly in association with beach deposits from the MIS 5e high sea-level stand, which is dated at c. 134116 ka by a combination of biostratigraphic indicators (principally the presence of the mollusc Persististrombus latus (previously Lentigo latus and Strombus bubonius) and radiometric dates (Ronen et al. 2008a, b; Galili et al. 2007, 2017e; Mauz et al. 2013; Benjamin et al. 2017; Porat et al. 2018). Scattered flint artefacts have also been recovered from the hamra palaeosols embedded between or within the kurkar ridges on the coast, and these too are attributed to the same period of high sea level (Ronen 1977; Ronen and Chernikov 2010). Despite the evidence of sites in MIS 5e shoreline settings, the nature of the activities practised by their occupants, in particular whether or not they exploited marine resources, is unclear. Occasional pieces of mammalian bone recovered in the MIS 5e beach deposits indicate terrestrial hunting, while marine shells in these sites may either be anthropogenic or natural in origin. Marine mollusc shells are also present in inland sites of about this period including Skhul, Qafzeh and Sefunim caves (Bar-Yosef Mayer et al. 2009), indicating visits to the shoreline or exchange relations with people living on the coast, but the shells were collected to make ornaments and are not definitive evidence that molluscs served as dietary items.

The region is also of importance as one of the earliest centres for the development of plant and animal domestication. This process is now thought to have begun over wide areas of the Near East perhaps as early as the Pre-Pottery Neolithic A period (PPNA) c. 11,000-10,500 cal $\mathrm{BP}$, with progressive expansion of crop cultivation and animal domestication and a concomitant reduction in hunting and gathering throughout the following PPNB and PPNC periods (c. 10,500-8400 cal BP) (Simmons 2007; Zeder 2011). The subsequent Pottery Neolithic period (PN) lasted from about 8400-6800 cal BP and has been sub-divided into several major cultural phases: from oldest to youngest, the Yarmukian, Jericho IX, the Lodian and the Wadi Rabah cultures, though there may have been some overlap between them (Table 23.1; Gopher and Gophna 1993; Gopher 1995, 2012; Garfinkel 1999). People lived in small sedentary villages dependent on animal husbandry (of caprines, cattle and pigs) and agriculture (cereals and legumes). Hunting had largely ceased as can be seen by the marked decrease in wild fauna and arrowheads (Gopher and Gophna 1993; Simmons 2007). Sickle blades are abundant and are shorter and wider than those found in the PPN, perhaps indicating a wider range of cultivars (Barkai and Gopher 2012).

Few Neolithic sites are known on the presentday Israeli-Gazan coastal plain-exceptions are Ashkelon (PPNC) and later PN sites of Ziqim, Nizzanim and Qatif Y2 (Gaza, Palestinian Authority), and this situation has changed little since the 1990s (Gopher and Gophna 1993; 
Gopher 1995). The paucity of Neolithic sites on the present-day coast may be in part due to sealevel rise during the early Holocene, which inundated areas of the coastal plain where Neolithic village settlements might have been located (e.g. Galili and Weinstein-Evron 1985; Galili 1985, 2004; Galili et al. 1988, 2005a; Sivan et al. 1999). The discovery of underwater settlements as described below confirms this interpretation and demonstrates the importance of underwater investigations in filling apparent gaps in the archaeological sequence as recorded on dry-land sites.

In total, there are records of 23 submerged prehistoric sites in Israel, including 1 Middle Palaeolithic, 2 Epipalaeolithic, 19 Neolithic/ Early Chalcolithic and 1 of uncertain period (possibly dating to the Late Pleistocene-Early Holocene). ${ }^{1}$ The Neolithic sites belong to three cultural phases: the Pre-Pottery Neolithic C (PPNC), represented by the site of Atlit-Yam, c. 9400-8000 cal BP; the early Pottery Neolithic site of Neve-Yam North belonging to the Lodian (Jericho IX) culture, dated by association to the first half of the seventh millennium BP; and 17 Pottery Neolithic/Early Chalcolithic sites belonging to the Wadi Rabah culture dated between c. 7800 and $7300 \mathrm{cal}$ BP. The Pottery Neolithic sites are located close to the present shore (1-200 m offshore) at depths of 0-5 m, while the older Atlit-Yam site is located further offshore (200$400 \mathrm{~m})$ and in deeper water $(8-12 \mathrm{~m}$ below sea level).

\subsection{Submerged Middle and Upper Palaeolithic Sites}

\subsubsection{Kfar Samir Centre}

Located on the southern municipal beach of the town of Haifa (Fig. 23.1), this Middle Palaeolithic site, most likely belonging to the Middle-Late Mousterian, comprises hundreds of scattered flint

\footnotetext{
${ }^{1}$ Some of these 23 sites are sectors of larger sites, e.g. Neve-Yam North and South, and these sectors have separate entries on the map and in the SPLASHCOS Viewer.
}

implements, orange in colour, embedded in a clay palaeosol, some produced by the Levallois technique (Galili and Weinstein-Evron 1985). These artefacts may have been washed out by stream action from the nearby Mount Carmel. Some of the retouched artefacts show two stages of patination, indicating that they may have been re-used by the later Neolithic inhabitants of the site (see PN sites below).

\subsubsection{Caesarea South Anchorage}

This site is located at the south-east corner of the south anchorage at Caesarea, at 1-2 m depth, some 20-50 m offshore (Fig. 23.1). The remains are embedded in a hamra soil that was exposed on the sea bottom after a storm (Galili 1985, p 22, 27; SPLASHCOS viewer site 23). The finds consist of 12 flint implements, including 6 microlithic bladelets, a few flakes, core fragments and an exhausted core. These finds are probably associated with the terrestrial Epipalaeolithic sites of Heftzibah and Nahal Hadera containing similar flint industries found on the surface in exposures of red loam some 1000-1500 m to the south-east (Ronen et al. 1975; Ronen and Kaufman 1976).

\subsubsection{Nahal Beit Haemeq (Shavei Tzion)}

The site is located between the modern settlements of Shavei-Tzion and Nahariya, at a water depth of 5-8 $\mathrm{m}$ and 150-250 $\mathrm{m}$ offshore (Fig. 23.1). A palaeosol was exposed on the sea bottom. Skull remains of a large herbivore (probably wild cattle) were discovered in the clay (Galili 1985: p 26, 30; L. Horwitz pers. comm. 1991). Several non-diagnostic flint artefacts were recovered close to the skull. The similar geological settings of the clay palaeosol to that of the Carmel coast (see above) and the proposed age of the Carmel coast palaeosol (Upper Pleistocene to Early Holocene) suggests an Epipalaeolithic or Neolithic cultural association for the material.

Given the time that has elapsed and the likely impact of underwater currents and pre-inundation 
alluvial processes, these finds may not be in situ and lack features such as hearths or structures. They offer similar evidence as found in the openair sites associated with the MIS 5e beach deposits (Ronen et al. 2008a; Galili et al. 2017e; Porat et al. 2018). The small number of finds in the MIS 5e sites and in the inundated sites described above suggests that they were most likely seasonal or short-lived camps, leaving behind scanty remains. This contrasts with inland caves such as those on Mount Carmel, which were never inundated, and were repeatedly visited over long periods of time, resulting in deep sequences of occupation and the accumulation of large assemblages of stone artefacts and faunal remains.

\subsubsection{Submerged Stone Mounds on the Carmel 'Nose' Rocky Surface}

This locality is of unknown date, but we include it here as it may be pre-Neolithic. It comprises several man-made stone piles that were discovered west of Cape Carmel (Galili 1981, pp 56-57; Galili et al. 2019a) on a flat, rocky sea floor c. 2 x $2 \mathrm{~km}$ known as the submerged Upper Carmel 'Nose' (Fig. 23.1, see also Fig. 23.24). These round stone features (2-4 $\mathrm{m}$ in diameter, up to $0.8 \mathrm{~m}$ in height) are composed of rounded, undressed limestone rocks of various sizes $(15-30 \mathrm{~cm})$. The piles are scattered over an area of $800 \times 800 \mathrm{~m}$ at depths of 4-7 m. The lack of small finds in and around these stone arrangements makes dating impossible. These structures require further research to determine their period and function. Given their depth and the local sea-level changes, they may be dated as Pottery Neolithic/Chalcolithic or they may be ballast from later shipwrecks.

\subsection{Submerged Neolithic Villages: Pre-Pottery Neolithic Atlit-Yam}

Atlit-Yam is located in the North Bay of Atlit, $10 \mathrm{~km}$ south of Haifa, 200-400 m offshore, 8-12 m below sea level (Fig. 23.2), and is well dated by radiocarbon dates on charcoal and waterlogged plant remains to the PPNC period c. 9400-8000 cal BP (Table 23.2). The site covers approximately $40,000 \mathrm{~m}^{2}$ and offers a unique opportunity to examine a large settlement and its surrounding terrain (Galili 2004).

The site is covered by 1-2 $\mathrm{m}$ of sand, parts of which are randomly removed by natural storms. Thus, exposure of different sectors of the site is accidental, unpredictable and cannot be preplanned. During exposure, the site erodes and finds may shift or be damaged. After significant storms, the site was surveyed by scuba diving to locate newly exposed areas and a rapid rescue and conservation operation, including excavation and documentation, was carried out. After several decades, separate documentation in isolation of many different areas of the site has resulted in enough 'jigsaw' pieces to provide quite a complete picture of the overall site pattern.

Excavation of the site was carried out both manually and using a dredging system within a laid-out grid (Fig. 23.3), and finds were taken ashore for sieving, conservation and more detailed analysis (see Galili et al. 2017b for further detail).

\subsubsection{Architectural Remains}

These comprise the foundations of several rectangular dwellings built of two rows of undressed kurkar stones, hearths, 2 megalithic ritual structures, stone-built water wells and about 20 circular stone-lined storage pits (Fig. 23.2). Other architectural remains identified are straight walls up to $60 \mathrm{~m}$ long (Fig. 23.2, Inset B, area F), a pair of thick parallel walls $1 \mathrm{~m}$ apart (Fig. 23.2, Inset A, 54; Fig. 23.4), a mudbrick wall (Fig. 23.2, area A), concentrations of burnt mudbricks and stonepaved floors (Galili and Weinstein-Evron 1985; Galili et al. 1993; Galili 2004, pp 42-55, 357366; Galili and Rosen 2011a). The layout of the settlement indicates a cluster of family units with dwellings, courtyards, storage pits and open spaces between them which could have been used for crop cultivation or keeping of domestic animals. This is in marked contrast to the con- 


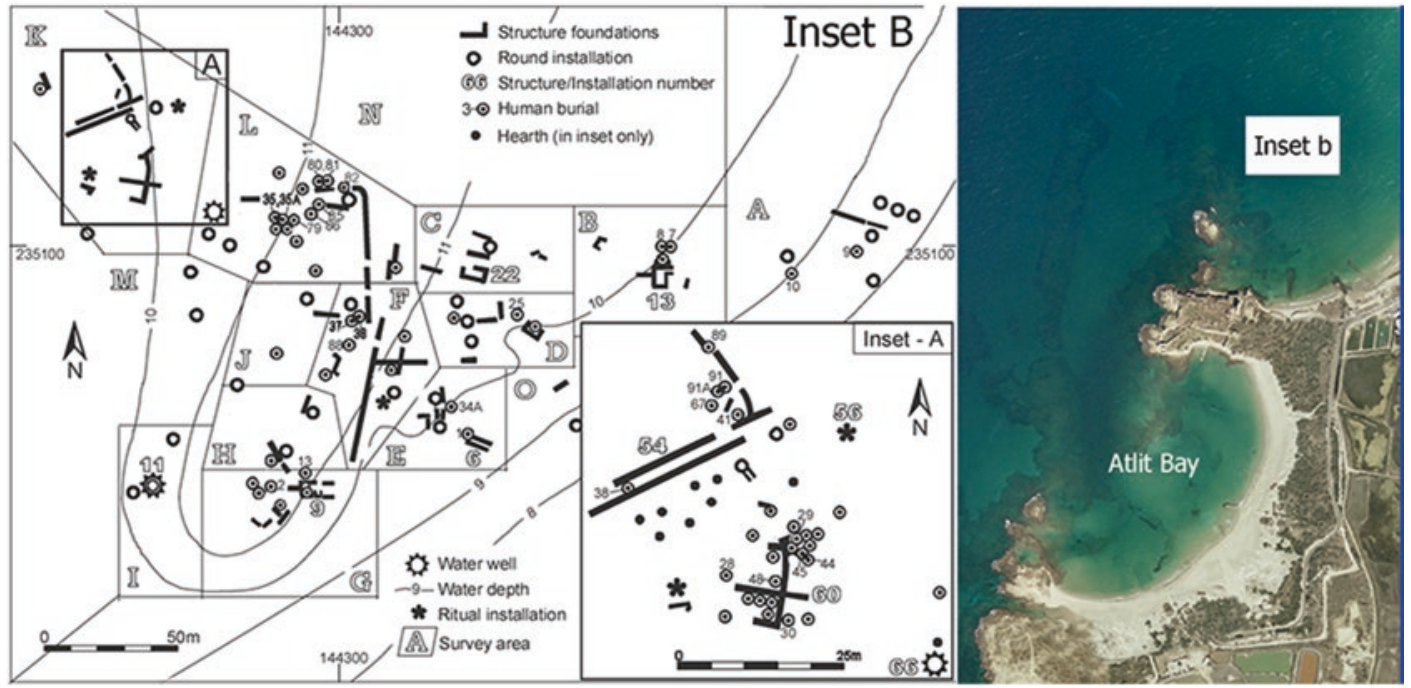

Fig. 23.2 Location and site plan of Atlit-Yam site. R: Aerial view of Atlit Bay showing the location of the site (Inset B); L: Plan of the site showing the location of dwelling structures, human burials, wells and other features. Drawing by Ehud Galili

temporaneous coastal site of Ashkelon, where dwelling pits, hearths and a wall were identified suggesting that this was a seasonal camp site (Garfinkel and Dag 2008).

\subsubsection{Water Wells}

Unique finds at Atlit-Yam are the circular stone-built features $0.8-1.5 \mathrm{~m}$ in diameter. Three of these were excavated and identified as water wells, representing the earliest constructed water wells in the world, while the others may represent water wells or storage pits (Galili and Nir 1993; Galili 2004, pp. 55-63, 367-368; Galili and Rosen 2011b).

The largest and most fully excavated well (well no. 11, area I) is a cylindrical shaft, $5.7 \mathrm{~m}$ deep and $1.5 \mathrm{~m}$ in diameter (Fig. 23.5). The uppermost three courses projected above the preexisting land surface and were still in situ and visible on the sea floor when first discovered. In antiquity, the upper part of the well shaft was dug through clay sediments and lined with c. 28 courses of undressed stones. The base of the well was then dug for about $1.5 \mathrm{~m}$ into the underlying kurkar bedrock in order to tap into the freshwater aquifer (Fig. 23.6). The fill of the well contained soft sandy clay, and kurkar stones of various sizes, many of them heat-fractured, numerous animal remains, flint and stone artefacts and considerable amounts of waterlogged and charred plant remains. The bottom $2 \mathrm{~m}$ of fill contained layers of large kurkar stones and almost no animal bones. These large stones are interpreted as an attempt to raise the base of the well to tap into a higher level of the freshwater aquifer in response to sea-level rise and saltwater seepage. Three radiocarbon dates from this lowest fill give a date range of 8540-7930 cal $\mathrm{BP}$, representing the latest possible age for the well construction (Table 23.2; Galili 2004).

The upper layers of the fill consist of similar components to the lower ones, in addition to numerous animal bones, some partly articulated, indicating that food waste was dumped there. The finds suggest that in this period the well had ceased to function as a freshwater source, most likely because of further sea-level rise and salinization, and served as a rubbish dump.

A second well (well 66, area L) was partially excavated to a depth of $1 \mathrm{~m}$ and shows similar features, with radiocarbon dates at the base of 8977-8187 cal BP (Table 23.2). In 2011, during the SPLASHCOS field school, a third well (well 
Table 23.2 Radiocarbon dates: RT=Weizman Institute, Israel (Segal and Carmi 1996; Boaretto E. personal communication-unpublished report 2005); PITT=Pittsburgh, USA; PTA=Pretoria, South Africa, Beta=Beta Analytic Inc., Miami, Florida, HV=Hanover Radiation Laboratories USA

\begin{tabular}{|c|c|c|c|c|c|}
\hline \multirow[b]{2}{*}{ Site } & \multirow[b]{2}{*}{ Lab reference } & \multirow{2}{*}{\begin{tabular}{|l}
${ }^{14} \mathrm{C}$ Age \\
$\mathrm{BP}$
\end{tabular}} & \multirow{2}{*}{$\begin{array}{l}\text { Calibrated age } \\
2 \sigma \text { range }(95.4 \%) \mathrm{Cal} \mathrm{BP}\end{array}$} & \multirow[b]{2}{*}{ Material } & \multirow[b]{2}{*}{ Provenance } \\
\hline & & & & & \\
\hline \multirow[t]{15}{*}{ Atlit-Yam } & PTA 3950 & $8000 \pm 90$ & 9112-8598 & Charcoal & Area B, 13 \\
\hline & RT 707 & $8140 \pm 90$ & $9402-8775$ & Charcoal & Area B, 13 \\
\hline & RT 944A & $7670 \pm 85$ & $8628-8340$ & Charcoal & Area E, 10A \\
\hline & RT 944C & $7610 \pm 90$ & $8590-8206$ & Charcoal & Area E, 10A \\
\hline & PITT 0622 & $7550 \pm 80$ & $8518-8186$ & Charcoal & Area E, 10A \\
\hline & RT 1431 & $7300 \pm 120$ & $8374-7933$ & Wood & Area I, Well 11 \\
\hline & RT 2479 & $7460 \pm 55$ & $8379-8181$ & Wood & Area I, Well 11 \\
\hline & RT 2477,78 & $7605 \pm 55$ & $8540-8336$ & Wood & Area I, Well 11 \\
\hline & RT 2475 & $7465 \pm 50$ & $8376-8187$ & Wood & Area I, Well 11 \\
\hline & RT 2495,93 & $7755 \pm 55$ & $8628-8420$ & Wood & Area L, Well 66 \\
\hline & RT 2489 & $7880 \pm 55$ & $8977-8555$ & Wood & Area L, Well 66 \\
\hline & RT 2681 & $6580 \pm 35$ & $7563-7427$ & Charcoal & Area E, 32 \\
\hline & RT 3038 & $8000 \pm 45$ & $9010-8659$ & Charcoal & Area K, 54 \\
\hline & RT 3043 & $7250 \pm 45$ & $8169-7980$ & Charcoal & Area K, 56 \\
\hline & RT 2497,96 & $8170 \pm 55$ & 9281-9007 & Charcoal & Area E, 65 \\
\hline \multirow[t]{3}{*}{ Neve-Yam } & HV 4256 & $6310 \pm 395$ & $7951-6323$ & Charcoal & Northern area \\
\hline & RT 1723 & $6390 \pm 70$ & $7430-7174$ & Charcoal & Southern area, graveyard \\
\hline & RT 1724 & $6565 \pm 70$ & $7579-7326$ & Charcoal & Southern area, graveyard \\
\hline \multirow[t]{21}{*}{ Kfar Samir } & Beta 82851 & $5860 \pm 140$ & $7146-6323$ & Wood & Central, Well 13 \\
\hline & RT 682B & $6470 \pm 130$ & $7613-7030$ & Wood & Central, Well 5 \\
\hline & RT 682A & $6670 \pm 160$ & $7786-7320$ & Wood & Central, Well 3 \\
\hline & PTA 3820 & $6830 \pm 80$ & $7844-7520$ & Wood & Central, Well 5 \\
\hline & PTA 3821 & $6830 \pm 160$ & $7964-7431$ & Wood & Central, Well 3 \\
\hline & Beta 82850 & $6940 \pm 60$ & $7930-7667$ & Wood & Central, Pit 10 \\
\hline & Beta 82845 & $6080 \pm 70$ & $7162-6783$ & Olive pit & Central, 6 \\
\hline & Beta 82846 & $6210 \pm 150$ & $7424-6751$ & Olive pit & Central, 6 \\
\hline & Beta 82847 & $6210 \pm 80$ & $7288-6897$ & Olive pit & Central, 6 \\
\hline & Beta 82848 & $6230 \pm 80$ & $7310-6930$ & Olive pit & Central, 6 \\
\hline & Beta 82715 & $6500 \pm 70$ & $7560-7273$ & Olive pit & Central, 6 \\
\hline & RT 1898 & $5790 \pm 55$ & 6729-6466 & Olive pit & Central, 6 \\
\hline & RT 1930 & $5870 \pm 70$ & $6877-6497$ & Olive pit & Central, 6 \\
\hline & Beta 82843 & $6100 \pm 60$ & $7162-6793$ & Olive pit & Central, 7 \\
\hline & Beta 82844 & $6290 \pm 60$ & $7413-7128$ & Olive pit & Central, 7 \\
\hline & RT 1929A & $5630 \pm 55$ & $6531-6299$ & Olive pit & Central, 7 \\
\hline & RT 1929 & $5870 \pm 70$ & 6877-6497 & Olive pit & Central, 7 \\
\hline & Beta 82849 & $6350 \pm 90$ & 7434-7019 & Wood & Central, 8 \\
\hline & RT 855 & $6420 \pm 120$ & $7568-7027$ & Mat fragment & Central, 8 \\
\hline & RT 1360 & $7230 \pm 80$ & $8275-7872$ & Wooden bowl & South \\
\hline & Beta 433765 & $6890 \pm 30$ & 7791-7667 & Wood & Central, Well 13 \\
\hline \multirow[t]{4}{*}{ Tel Hreiz } & RT 799A & $7330 \pm 120$ & 8379-7952 & Wood & Northern \\
\hline & PTA 3460 & $6310 \pm 70$ & $7418-7025$ & Wood & Northern \\
\hline & RT 779B & $6260 \pm 150$ & $7440-6791$ & Wood & Northern \\
\hline & RT 2480 & $6150 \pm 30$ & 7159-6958 & Wood & Northern \\
\hline \multirow[t]{3}{*}{ Megadim } & PTA 3652 & $7960 \pm 70$ & $8983-8484$ & Clay & Southern \\
\hline & PTA 3648A & $6310 \pm 70$ & $7418-7025$ & Bone & Southern \\
\hline & PTA 4339A & $6270 \pm 50$ & $7305-7018$ & Bone & Southern \\
\hline
\end{tabular}


Table 23.2 (continued)

\begin{tabular}{|c|c|c|c|c|c|}
\hline \multirow[b]{2}{*}{ Site } & \multirow[b]{2}{*}{ Lab reference } & ${ }^{14} \mathrm{C}$ Age & Calibrated age & \multirow[b]{2}{*}{ Material } & \multirow[b]{2}{*}{ Provenance } \\
\hline & & $\mathrm{BP}$ & $2 \sigma$ range $(95.4 \%) \mathrm{Cal} \mathrm{BP}$ & & \\
\hline \multirow[t]{3}{*}{ Kfar Galim } & RT 1748 & $5985 \pm 55$ & $6950-6676$ & Wood & Central, Well \\
\hline & RT 1749 & $5985 \pm 70$ & $7000-6662$ & Wood & Central, Well \\
\hline & RT 1750 & $6890 \pm 50$ & $7835-7623$ & Wood & Northern, branch \\
\hline
\end{tabular}

Calibration according to OxCal v 4.3.2 (Stuiver and Reimer 1993; Bronk Ramsey 2017; Reimer et al. 2013). Provenance refers to the area of the site and the feature number shown on the site plans

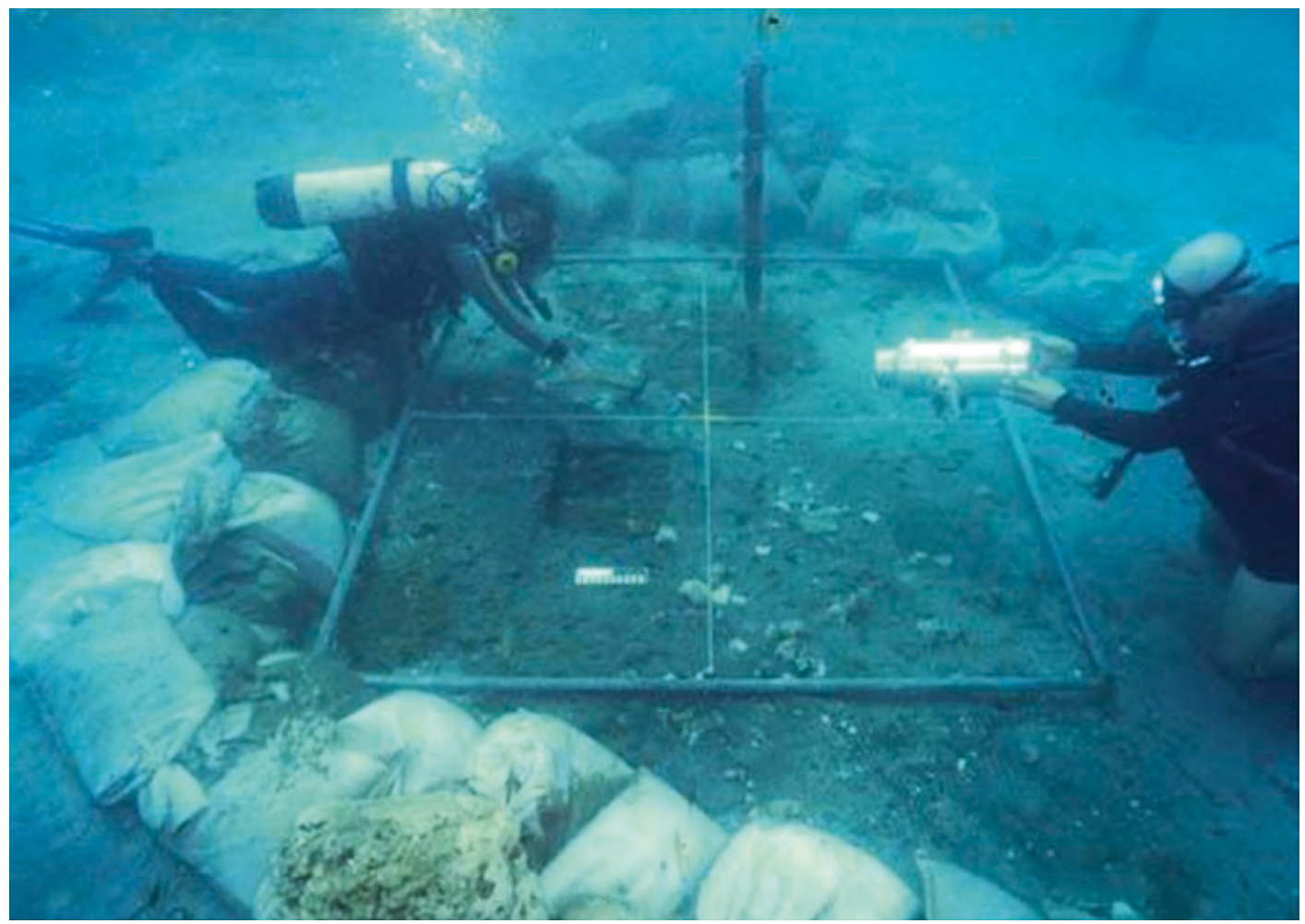

Fig. 23.3 Atlit-Yam structure 10a (concentration of fish bones and wheat grains) during the course of excavation. Photo by Ehud Galili

80, area M) was discovered and excavated to a depth of $30 \mathrm{~cm}$ (Galili et al. 2017b).

\subsubsection{Megalithic Structures}

Two were identified and consist of kurkar stones, some of which may have been partly shaped. The northern structure (Fig. 23.2, Inset A, 56) comprises large standing stones up to $1.8 \mathrm{~m}$ high, arranged in a circle with more stone slabs (up to $1 \times 1 \times 0.3 \mathrm{~m})$ lying horizontally to the west (Fig. 23.7; Galili 2004, pp. 48-50, 363-364; Galili and Rosen 2011a). Tens of cup marks were recovered in and around the structure, as well as traces of freshwater vegetation. The nature of the structure and the finds suggest that it was used for cultic purposes, probably associated with fresh water. About $20 \mathrm{~m}$ west of this structure, there are two parallel walls, $1 \mathrm{~m}$ apart, forming a corridor leading to the general area of the megalithic structure (Fig. 23.2, Inset A, 54). This corridor may have been part of the megalithic complex. Palaeo-astronomical calculations suggest that the orientation of the corridor could have been associated with the sunset during the longest day 


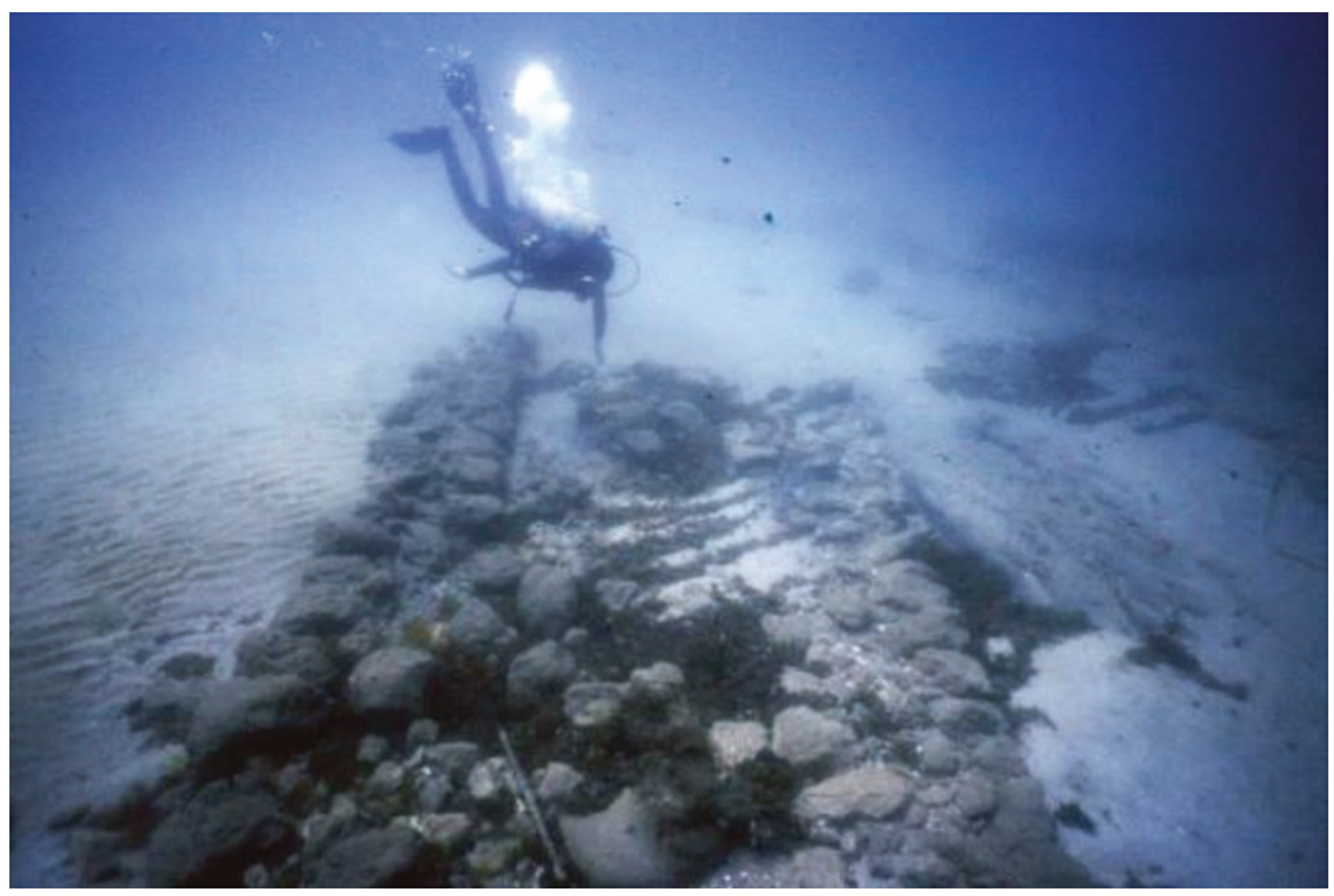

Fig. 23.4 Two parallel stone walls (structure no. 6) in area E, Atlit-Yam in $10 \mathrm{~m}$ of water. Photo by Ehud Galili

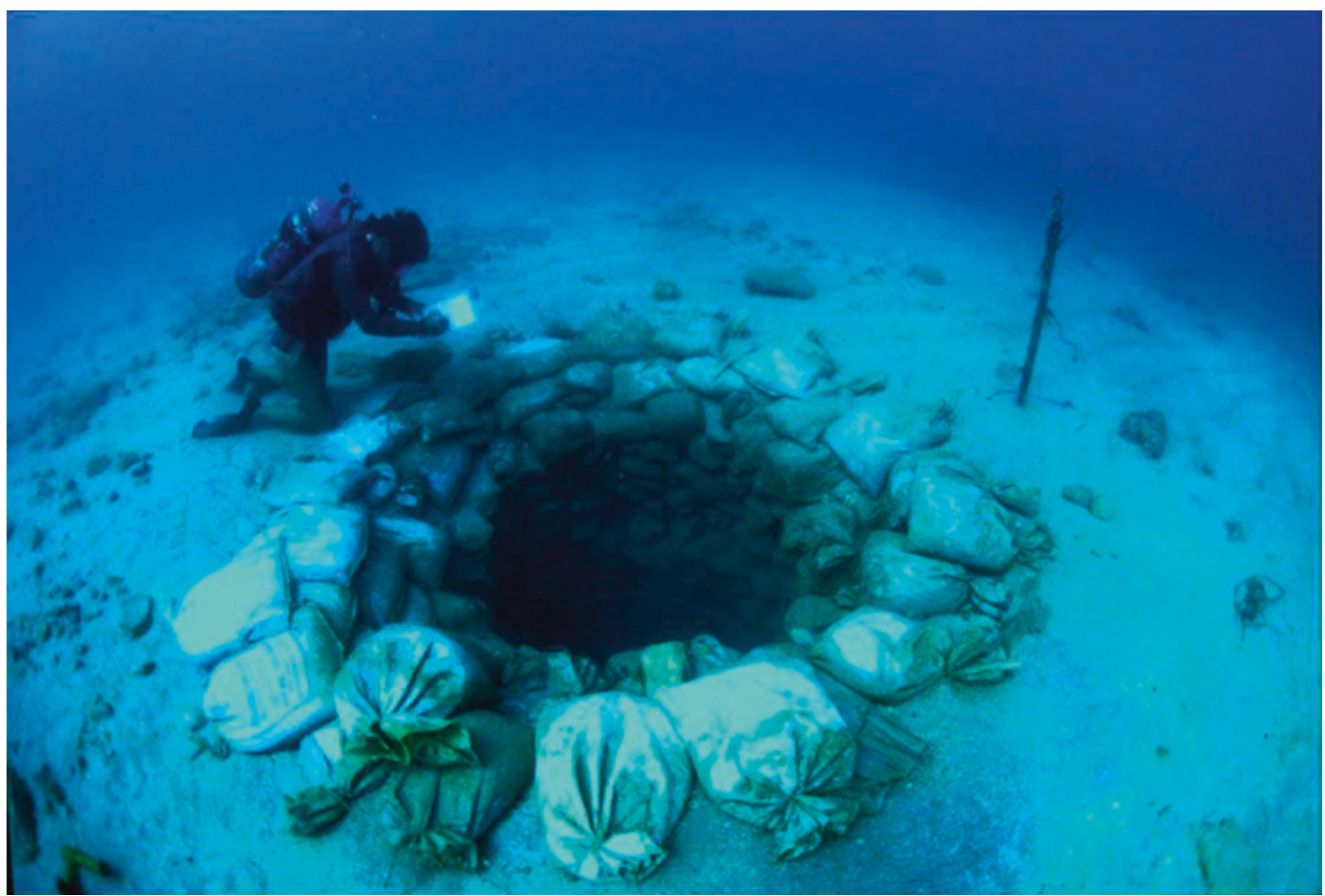

Fig. 23.5 Well no 11 at Atlit-Yam, showing a diver inspecting the upper mouth of the well. Photo by Itamar Grinberg 


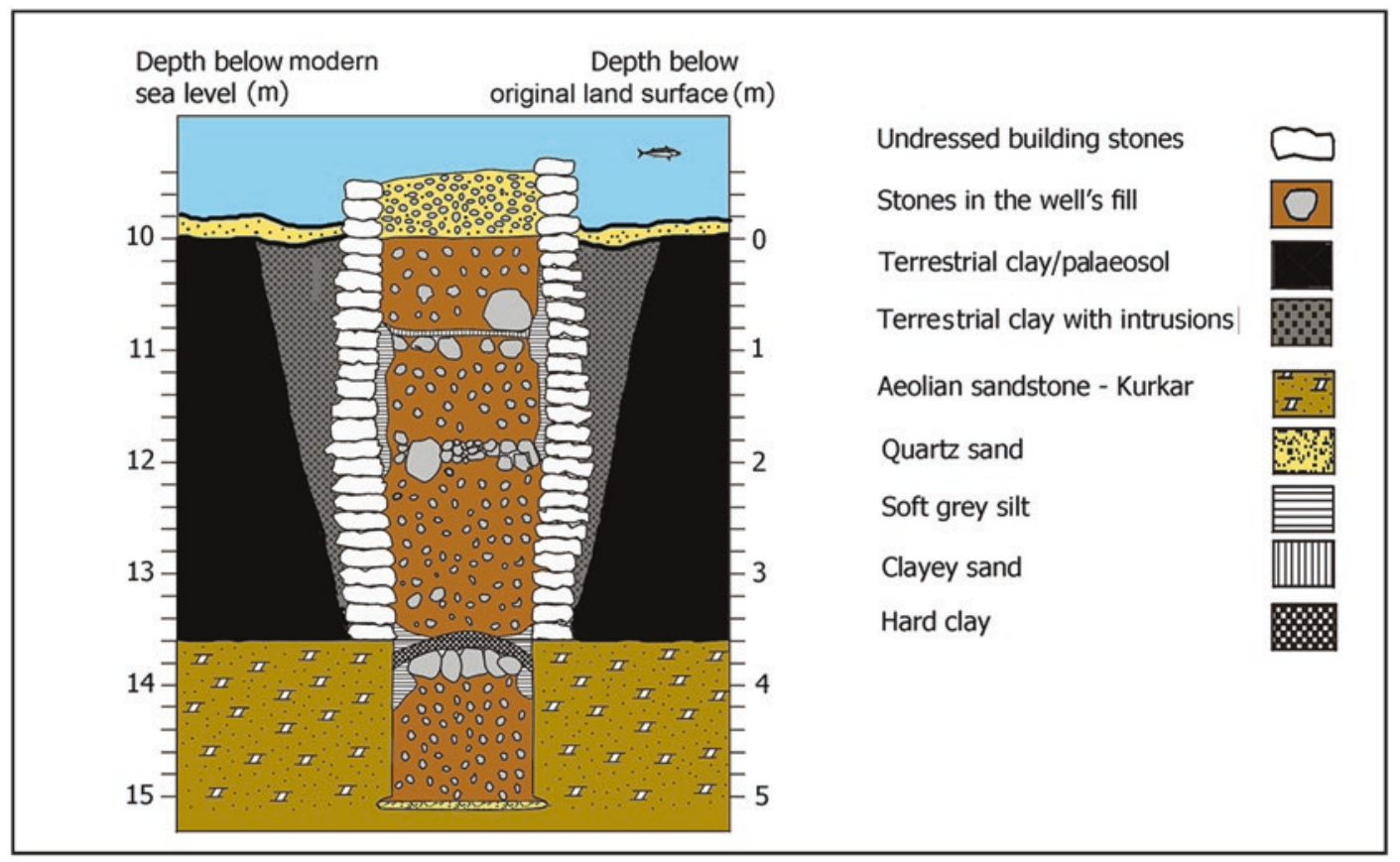

Fig. 23.6 Cross section of well no 11 at Atlit-Yam, showing the stone lining, the nature of the fill and the surrounding sediments. Note that the well has been dug $1.5 \mathrm{~m}$ into the kurkar bedrock. Note also the layers of stones near the base, which looks like an attempt to raise the base of the well to offset sea-level rise and salinization of the well. See text for further discussion. Drawing by Ehud Galili

of the year (Clive Ruggles pers. comm. 2010). The southern megalithic structure (Fig. 23.2, inset $\mathrm{B}$, area $\mathrm{E}$ ) is composed of three large stones, each c. $1.7 \mathrm{~m}$ long and weighing $450-550 \mathrm{~kg}$. Two of them are anthropomorphic in nature, having a circumscribed groove at one end to delineate a schematic head.

\subsubsection{Material Culture}

\subsubsection{Flint and Ground-Stone Artefacts}

At least three spatially discrete areas with different flint assemblages, indicating different activities, are distributed across the site (Galili 2004: pp. 95-126, 382-423): (1) a chipping floor or workshop with evidence of the manufacture, hafting and repair of tools such as arrowheads and axes, and with a high percentage of naviform cores with two striking platforms indicating specialized production of blades (area D); (2) an assemblage with a relatively high percentage of bifacial tools (areas K, L), indicative of extensive wood working (Barkai and Galili 2004; Barkai 2011), perhaps associated with production of water craft (Yerkes et al. 2014); and (3) an assemblage of mainly flint waste and exhausted cores deliberately dumped in the upper levels of well 11 after it had ceased to be used as a water source (area I).

In general terms, the flint assemblage at AtlitYam is similar to other PPN sites of the region, indicating a reduction over time in naviform cores and in the use of long blades manufactured from them, and a reduction in the percentage of arrowheads (Fig. 23.8: B, C). Two other features are worth noting. The first is the presence of flint daggers (Fig. 23.8: D). These are also found at other coastal sites like PPNC Ashkelon and PN Zikim but are rare in inland Neolithic sites. Given their geographic distribution, it is possible that they were particularly associated with exploitation of marine resources in activities such as spear fishing or gutting and processing of fish (Galili et al. 2004). 

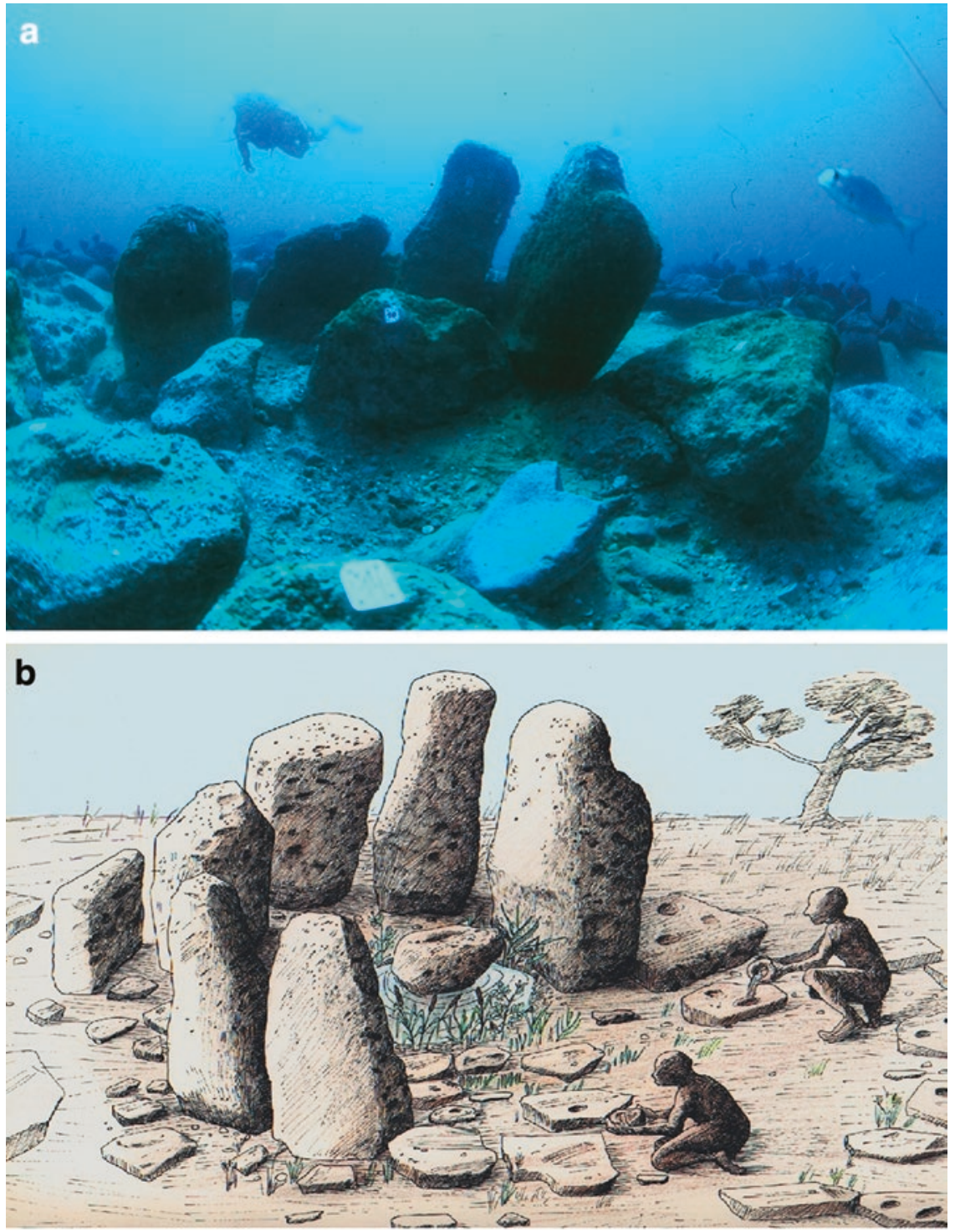

Fig. 23.7 The megalithic structure at Atlit-Yam showing standing stones arranged in a circle. (a) The structure after excavation. Photo by Itamar Grinberg; (b) Artist's reconstruction by the Israel Antiquities Authority

The second feature is the presence of denticulate sickle blades produced from long delicate blades extracted from naviform cores (Fig. 23.8, A). These blades were previously dated to the early PN (Yarmukian Culture). Some items recovered from the PPNC levels of 'Ain Ghazal (Jordan), were considered as intrusive from the overlying Yarmukian layers (Rollefson 1990; Rollefson et al. 1992; Garfinkel 1993). Their presence at Atlit-Yam, which is a single period
PPNC site, demonstrates for the first time their use in the PPNC period.

The ground-stone assemblage includes mainly containers such as large basins made of kurkar stone, polished bowls made of limestone and cup marks in slabs and boulders. Other finds are polished pebbles, hammer stones and grinding slabs. The reliance on stone containers in Atlit-Yam, compared to the submerged PN sites of Neve-Yam and Tell Hreiz, is probably due to the absence of 


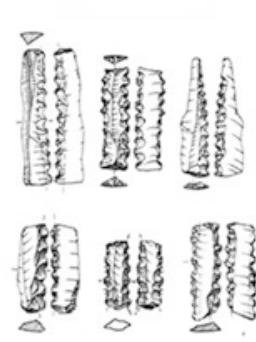

A
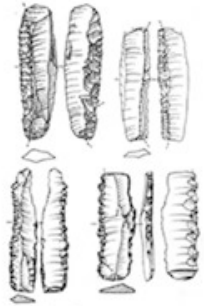

E)

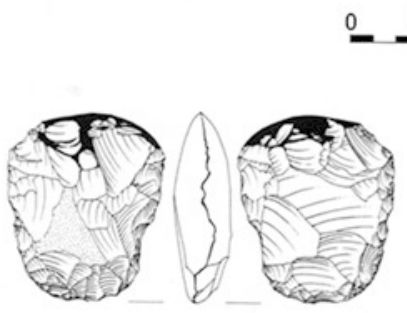

$\mathrm{D}$
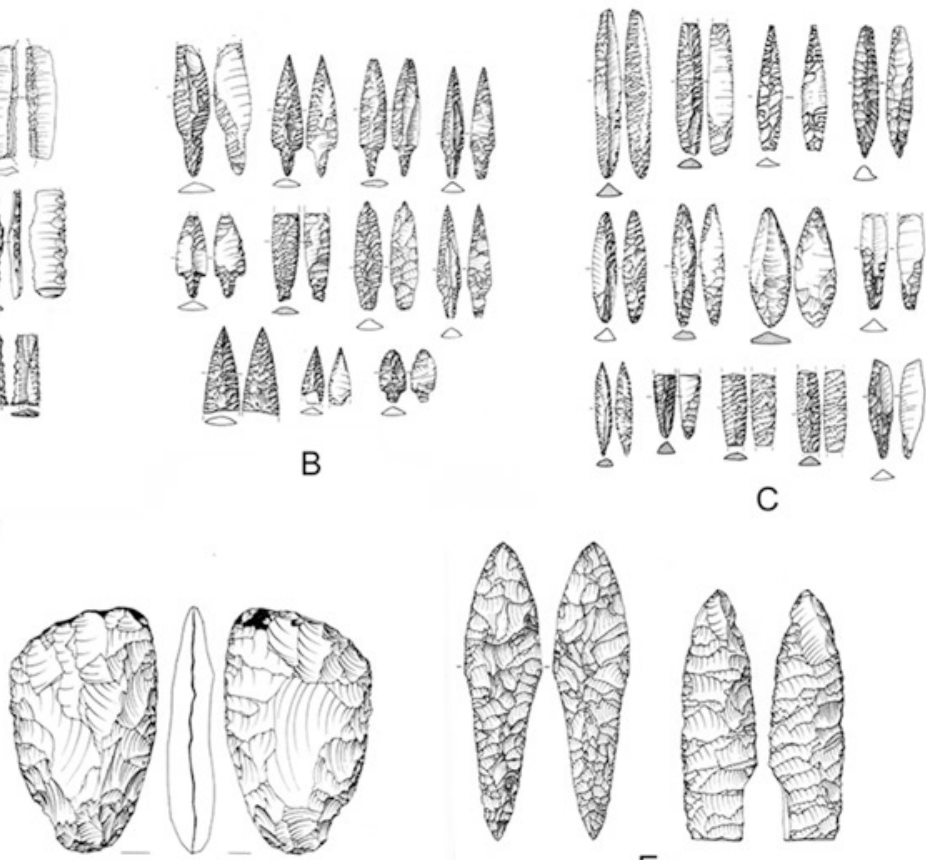

Fig. 23.8 Selection of artefacts from Atlit-Yam. (a) Sickle blades; (b) Byblos arrowheads; (c) Amuq arrowheads; (d) daggers; (e) bifacial axes. Courtesy of Israel Antiquities Authority

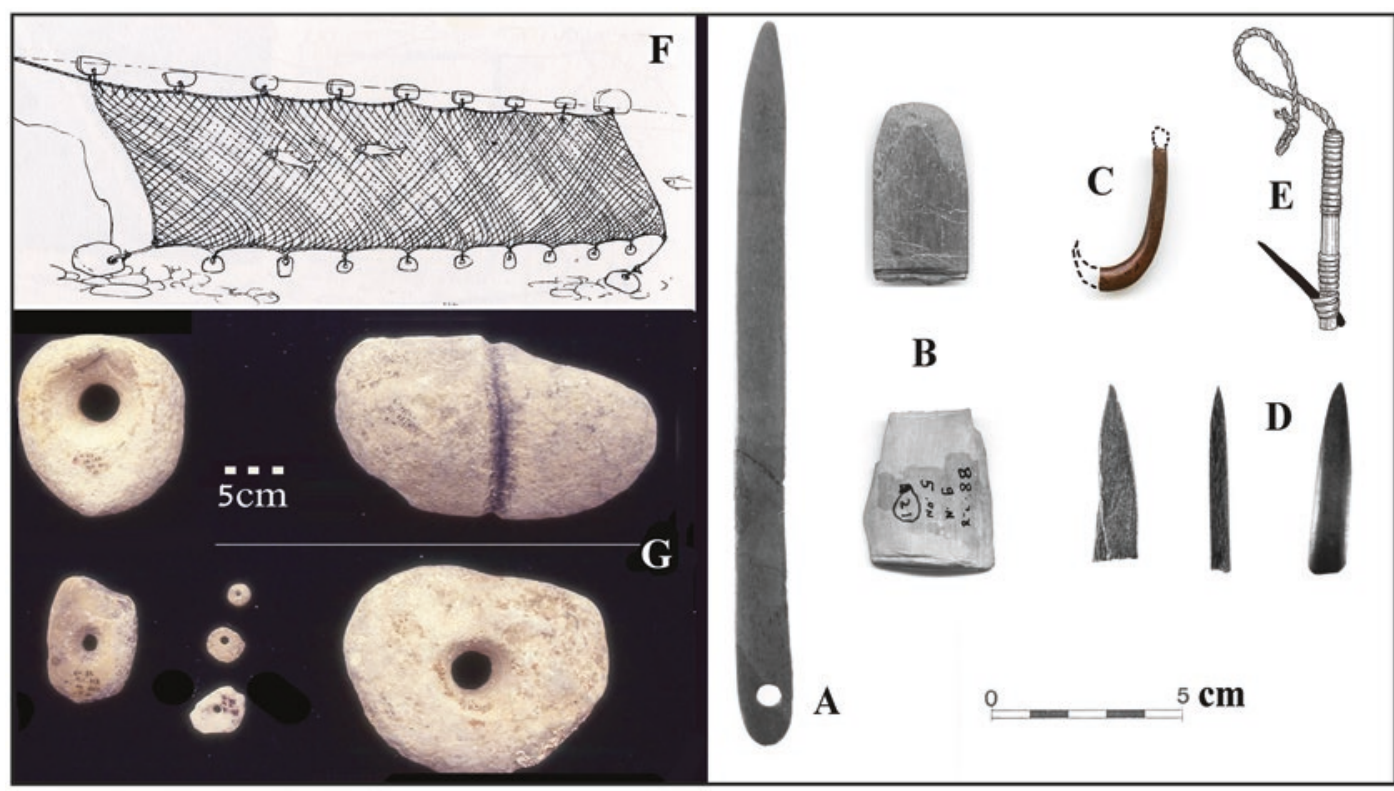

Fig. 23.9 Items of fishing gear at Atlit-Yam. (a) bone needle; (b) bone gauges for producing fishing nets; (c) bone fish hook; (d) bone barbs of composed fishing hooks; (e) artist's reconstruction of a barbed fishing hook; (f) artist's impression of a fish net with sinkers attached; (g) stone net sinkers (large perforated and circumscribed end sinkers and small perforated bottom-rope sinkers). Photo by Ehud Galili, reconstruction by the Israel Antiquities Authority 
pottery at the earlier site. Perforated stones recovered in the site may have been used as fishing-net sinkers (Fig. 23.9: G; Galili 2004, pp. 73-95, pp 375-380; Galili et al. 2013).

\subsubsection{Figurines and Ornaments}

Ornamented stone includes an anthropomorphic figurine depicting a female buttock, a phallus, decorated pendants, decorated discs and rings and a large rounded stone with two lines of regularly spaced holes that may have been used as a gaming board (Fig. 23.10, A). In one of the megalithic structures (No. 67), two of the kurkar stones bear circumscribed grooves, possibly representing anthropomorphic figures, as noted above.

\subsubsection{Plant and Animal Remains}

Thanks to the conditions of preservation, with material sealed in the sediment fill of abandoned wells or storage pits and further protected in anaerobic conditions by marine inundation, AtlitYam has provided an unusually rich, diverse and well-preserved collection of plant and animal remains, providing many new insights into the subsistence practices of the period.

\subsubsection{Plant Remains}

The plant material mostly comes from the fill of well 11 and consists of carbonised and waterlogged seeds or other parts of 91 species (Fig. 23.11: A) as well as tree branches and pol-

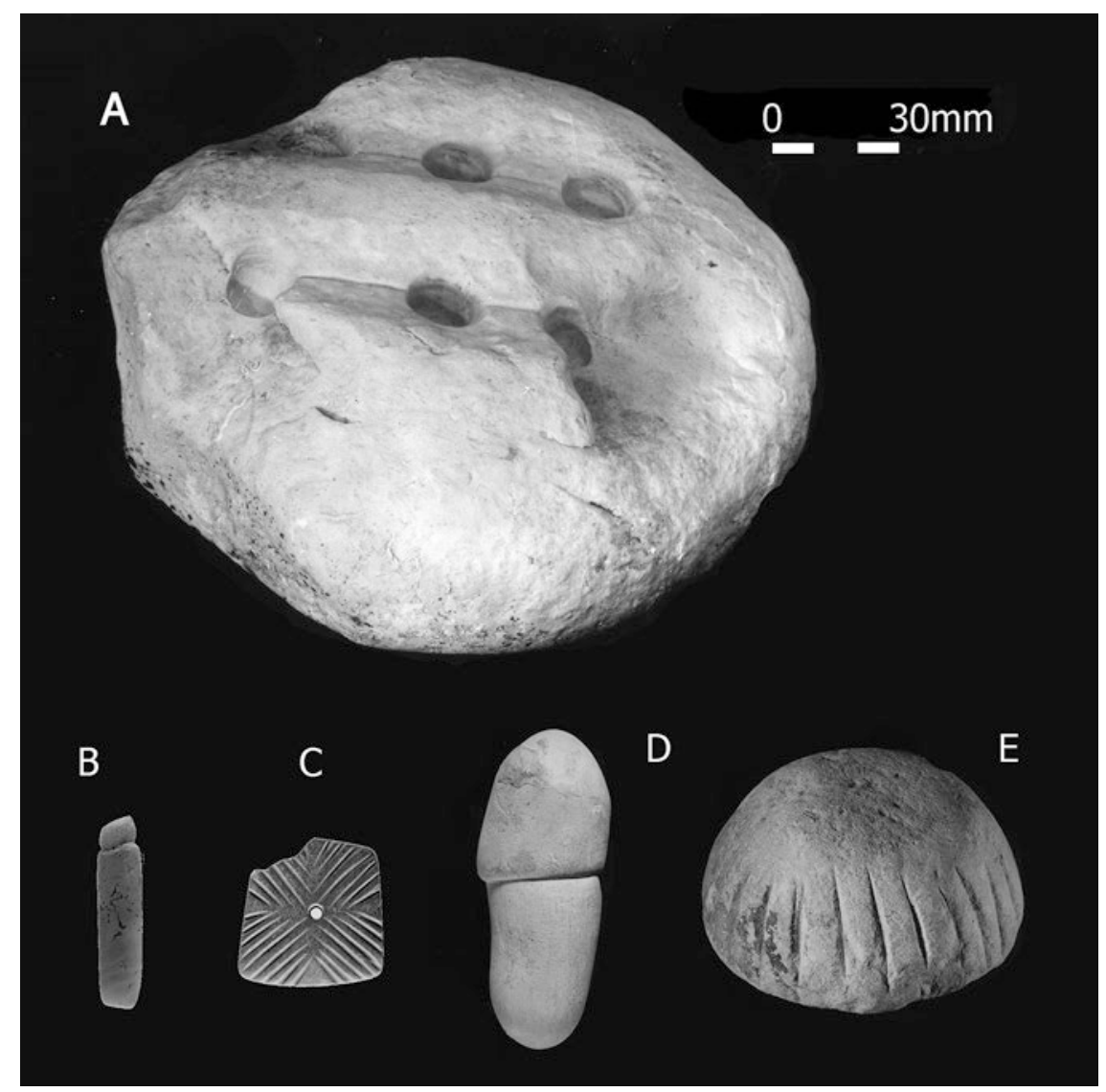

Fig. 23.10 Selection of stone items from Atlit-Yam. (a) Gaming board made of limestone; (b) decorated pendant made of calcite; (c) decorated item (button?) made of limestone; (d) limestone phallus; (e) decorated item made of limestone (miniature anvil?). Photos by Ehud Galili 
a

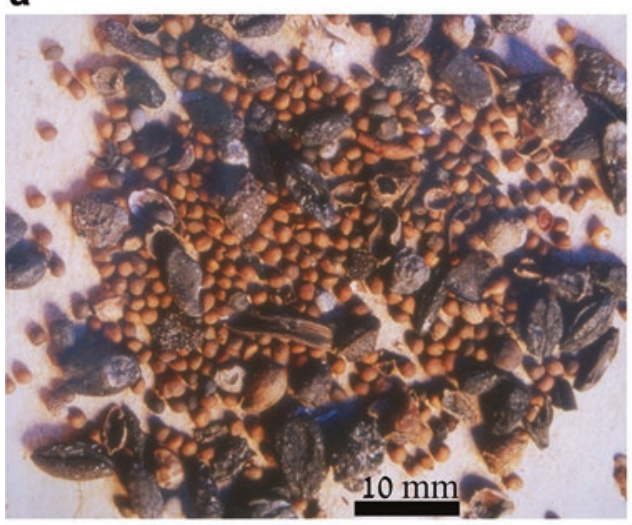

C

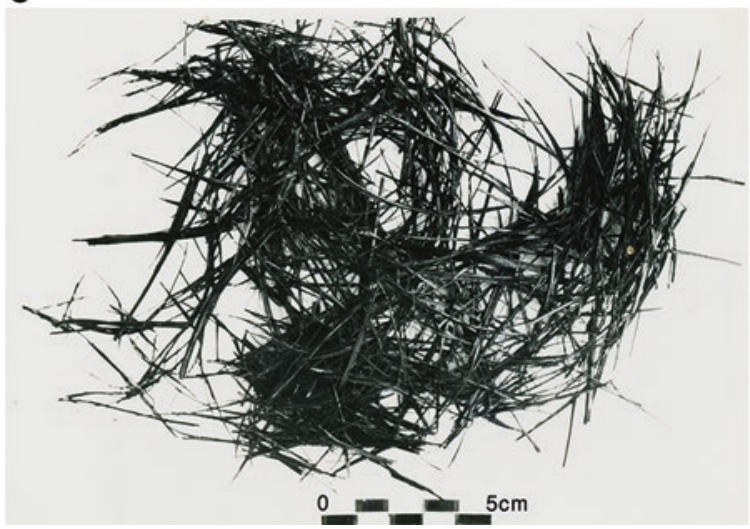

b

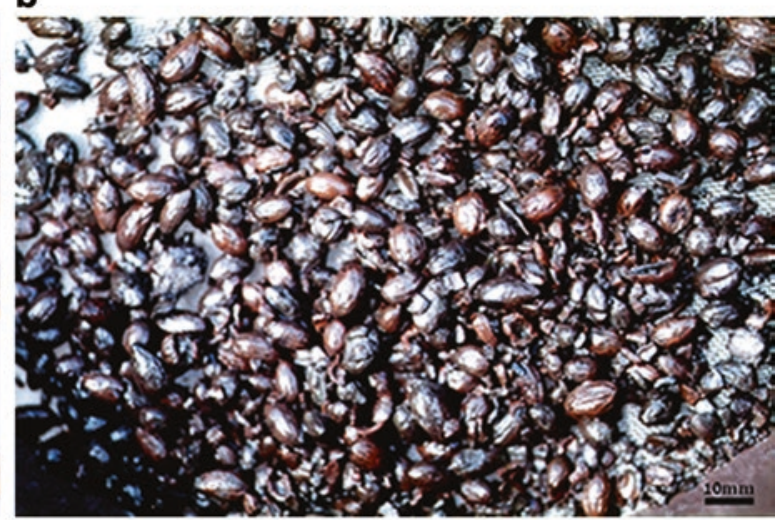

d

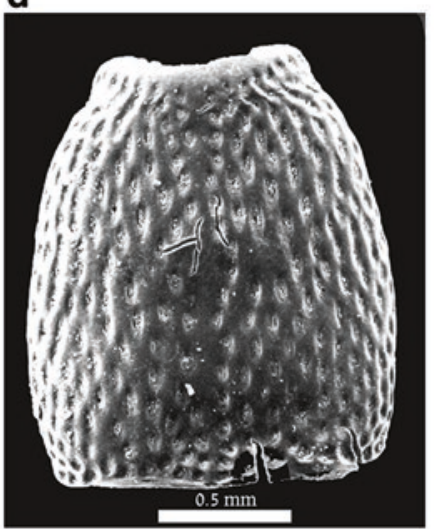

Fig. 23.11 Selection of items showing the preservation of uncharred organic materials. (a) seeds of figs and wheat grains; (b) olive pits; (c) remains of flax; (d) remains of grain weevil. Photos by Joseph Galili

len grains (Galili and Weinstein-Evron 1985; Galili et al. 1993; Weinstein-Evron 1994; Kislev et al. 2004). Domesticated crops include wheat (Triticum aestivum), barley (Hordeum vulgare), lentils (Lens lentis) and flax (Linum usitatissimит). Flax fibres were also recovered, perhaps used for making fish nets or fishing lines (Fig. 23.11: C). Seeds of wild fruit species include almonds (Amygdalus communis), figs (Ficus carica), grapes (Vitis sylvestris) and a single date (Phoenix theophrasti). Additionally, various seeds of plants commonly used as fodder were present (Galili et al. 2002, p. 182). The plant assemblage includes 'obligatory' weeds, plant species adapted to growing alongside cultivated crops, indicating that the plant ecosystem had already been modified by crop cultivation, and there are also 27 remains of the grain weevil
(Fig. 23.11: D), an obligatory grain pest (Sitophilus granarius), one of the earliest records in the Near East (Hartmann-Shenkman et al. 2015). One of the stone-built pits contained masses of waterlogged plant material identified as straw, probably used for animal fodder.

\subsubsection{Animal Remains}

Bones of terrestrial vertebrates (over 8000) are well preserved and include domestic goats (Capra hircus) and sheep (Ovis aries), cattle (Bos taurus), domestic pigs (Sus scrofa domestica) and dogs (Canis familiaris) (Horwitz and Tchernov 1987; Galili et al. 1993, 2002, 2004; Horwitz and Ducos 2005). Some of the cattle and goats resemble their ancestral wild forms suggesting an early stage of domestication. Wild species include wild boar (Sus scrofa ferus), mountain gazelle (Gazella 
gazella), Persian fallow deer (Dama dama mesopotamica), carnivores especially red fox (Vulpes vulpes), reptiles, rodents and amphibians. In the early phases of the settlement, wild animals and those in the initial stages of domestication were dominant, especially cattle. In contrast, in the fill of the well, representing a slightly later occupation stage, remains of juvenile animals were predominant, especially those of domestic goats, sheep, pigs and dogs. In both assemblages, butchery damage was evident with numerous cut and chop marks (Greenfield et al. 2013), but few of the bones were burnt.

More than 6000 fish remains (bones, scales, teeth) were recovered, representing seven families of Mediterranean marine fish but with the Grey triggerfish (Balistes carolinensis) accounting for the great majority. Some fish bones were blackened by fire, indicating direct association with human processing activities, and many fish bones were found concentrated in close association with archaeological remains, indicating that they were in situ food remains rather than more recent intrusions of natural death assemblages. A number of artefacts including the stone net sinkers referred to above reinforce the evidence for fishing as an important subsistence activity (Fig. 23.9). The size distribution of the fish remains suggests that fishing nets were used, and the pelagic fish bones recovered imply that offshore fishing with boats took place (Zohar et al. 1994, 2001; Galili et al. 2004).

The faunal assemblage from PPNC Ashkelon had a similar composition to that of Atlit-Yam, including a substantial fish component, suggesting a similar combination of hunting, herding and fishing (Hesse and Rookis 2008; Lernau 2008). However, the architectural remains suggest that Atlit-Yam was a permanent sedentary settlement, while Ashkelon was probably a seasonal site (see above).

\subsubsection{Human Burials}

Atlit-Yam yielded a very large number of human burials, with an estimated number of 63 individuals. Burials were found in all parts of the site. Most of the skeletons were found in organized graves adjacent to structures, but rarely within them; nevertheless, isolated bones were also found in different areas of the site. The latter probably represent disturbed graves due to build-
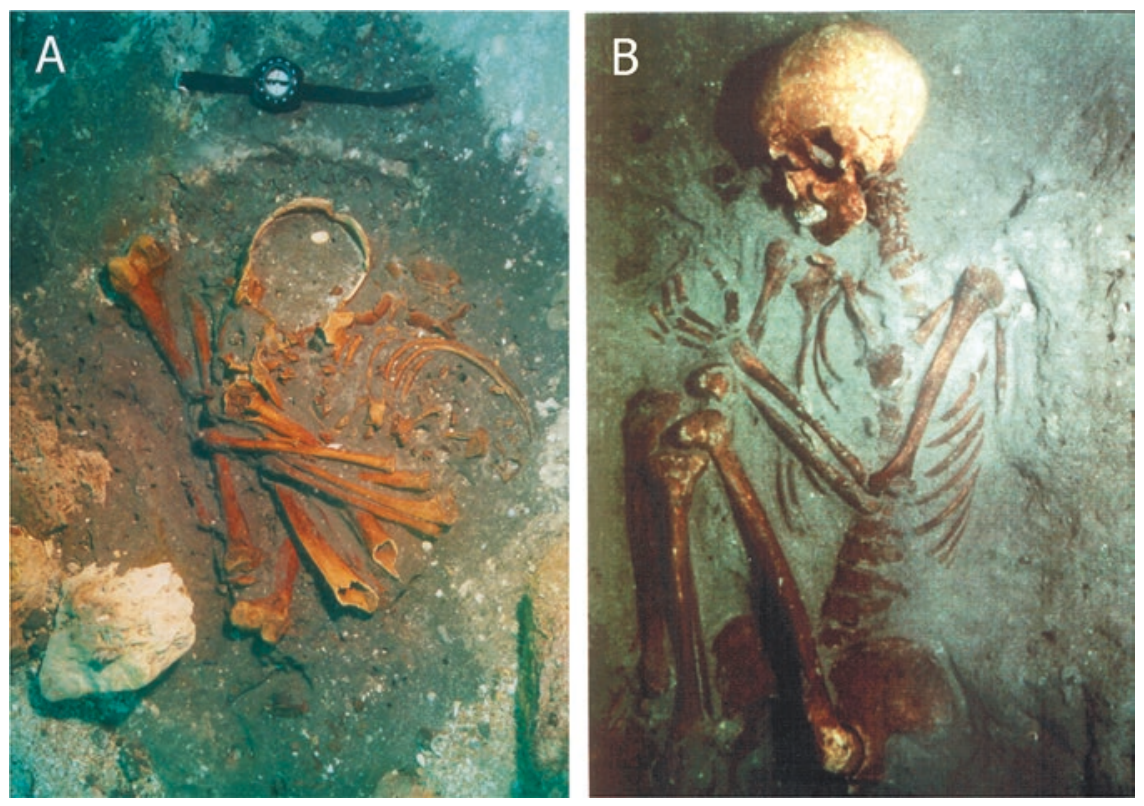

Fig. 23.12 Burials at Atlit-Yam: (a) primary burial of a woman in flexed position, (b) woman and infant, both with evidence of infection by tuberculosis. Photos by Ehud Galili 
ing and digging activities or renovation of structures from time to time (Galili et al. 2005b; Eshed and Galili 2011). Burials were mostly primary (Fig. 23.12). In six cases there was evidence of secondary burials. Of the 37 primary burials, 24 contained a single individual, 11 contained 2 individuals and 2 contained 3 individuals. Most of the deceased were found in a flexed or semiflexed position, with no clear pattern in orientation. Skulls were usually intact, but a few skeletons had no skull, and in one burial only the skull was found. Graves were simple pits dug into the clay and had no external markings. In some cases, a few small-sized stones were scattered at random on top of, or around, the pit. Most burials $(\mathrm{N}=45)$ were in the north-west area of the site (Fig. 23.2: areas K and L). Twentythree of these were adjacent to a single rectangular structure (no. 60) and were associated with hearths. It may well be that this group of burials is associated in some way with a nearby megalithic structure (Fig. 23.2, Inset A: 56) and a twowall corridor located c. $30 \mathrm{~m}$ to the north (see Fig. 23.2, Inset A: 60, 56 and 54).

Fifteen burials had grave offerings, five had flint axes, five had ground-stone tools, two had bone artefacts, and two had cattle horn cores and a calcite crystal. It seems that the type of offering was gender-based, stone axes with males and grinding stones with females (Barkai and Galili 2004).

Numerous skeletal pathologies were identified (Hershkovitz and Galili 1990; Galili et al. 2005b; Eshed et al. 2010). These include auditory exostosis, an ear pathology evident in $25 \%$ of the male skeletons, caused by diving or frequent swimming in cold water, perhaps indicating an engagement in underwater spear fishing. Thalassemia is also indicated, suggesting that the inhabitants of Atli-Yam were less susceptible to malaria, a mosquito-borne disease commonly associated with coastal swamps. Tuberculosis is confirmed by aDNA analysis (Hershkovitz et al. 2008; Donoghue et al. 2009) and is the earliest confirmed report of this disease in humans. An aDNA analysis of the Atlit-Yam cattle bones proved negative for the presence of Mycobacterium bovis, the bovine form of tuberculosis, suggesting the spread of the disease by human contact rather than from domestic cattle.

\subsection{Submerged Pottery Neolithic Sites}

There are 18 submerged PN sites. Some are sectors of sub-divided large sites. From north to south, they are as follows: Kfar Samir (north, centre and south), Hishuley Carmel (north and south), Kfar-Galim (north and south), Nahal Galim, Hahoterim, Tel Hreiz (north and south), Megadim, Atlit north bay, Neve-Yam (north, south, Temanun island and west) and Habonim. Based on radiocarbon dates (Table 23.2) and material culture, 16 are attributed to the Wadi Rabah culture, variously considered as late PN (Gopher and Gophna 1993; Gopher 2012) or early Chalcolithic (Garfinkel 1999). Recent C14 analysis of the Hishuley Carmel north site (not published here) attributes this site to the Middle Chalcolithic Period. The Neve-Yam north site includes pottery typical of the Lodian culture, which predates the Wadi Rabah culture (Table 23.1; Gopher and Gophna 1993; Galili 2004; Galili et al. 2017c).

\subsubsection{Methods}

These submerged Pottery Neolithic sites are located in shallow-water, high-energy marine environments in the intertidal and surf zones (0-7 m deep), posing methodological and logistical problems that required the development of novel survey and excavation methods (Galili et al. 1993, 2017b; Galili 2004). The eastern portions of these sites are usually $0-1 \mathrm{~m}$ deep, too shallow to apply the underwater excavation methods developed and described for sites in deeper water like Atlit-Yam. Waves interfere with the excavation and the visibility is poor. We adopted a strategy of allowing the sea to do the 
job of removing the overlying sandy sediments, as at Atlit-Yam. Most of the archaeological material was collected after storms, either during underwater surveys often undertaken by snorkelling, or sometimes even as washed up material on the shoreline. A few limited excavations were carried out in the deeper portions of these sites, at Kfar Samir central sector (water wells and pits), Kfar Galim and Megadim (stone-lined pits) and Neve-Yam (stone-built graves). The protocols for excavation and post-excavation treatment of material followed that for Atlit-Yam.

\subsubsection{Architectural Remains and Features}

After five decades of site exposure and documentation, considerable portions of the PN villages of Neve Yam, Tel Hreiz, Kfar Galim and Kfar Samir are available. Thus, the general nature and layout of these sites can be reconstructed. At Neve-Yam and Tell Hreiz, rectangular dwellings, round pits and stone-built graves were recovered. At the other sites, notably at Kfar Samir, stone paving slabs were found and features such as pits and water wells (the former also at Kfar Galim). In addition, hearths, c. $0.5 \mathrm{~m}$ in diameter, some lined with stones and containing fragments of burnt bone and charcoal, were also recovered at Kfar Samir. Tel Hreiz revealed evidence of rectangular structures, stone paving and hearths containing charred remains of wood and animal bones. At Hishuley Carmel, two stone-paved, elliptical features constructed of upright stone slabs were exposed near the shore at $0.8 \mathrm{~m}$ depth. Their fill contained a $15-\mathrm{cm}$-thick layer with thousands of olive stones preserved by waterlogging. At Tel Hreiz, two concentrations of vertical wooden poles made from tree branches were recovered. They are probably foundations of fences, huts or cabins. At this site, a stone-built wall $>100 \mathrm{~m}$ long was discovered, lying parallel to the present coast at $3-4 \mathrm{~m}$ depth. It was built of boulders up to $1 \mathrm{~m}$ in their maximum dimension and may have served as a seawall to protect the village from wave action and rising sea level (Galili and Rosen 2013; Galili et al. 2019b).

The Neve-Yam south site showed a layout sub-divided into two distinct areas, the northern one with remains of dwellings and domestic activities, while the southern one represents an organized burial ground (Fig. 23.13 and 23.14, B). In the north, there were foundations of rectangular structures and wall fragments (c. $0.5 \mathrm{~m}$ in width) built of two rows of undressed sandstone (Fig. 23.15). Also found were pits, paved surfaces made of small undressed stones, stone slabs and postholes, probably evidence of hut structures. In the south, cist graves built of standing stones arranged in an elliptical pattern and covered with stone slabs were found, all with an east-west orientation forming an organized pattern (Fig. 23.14, A, B). Between the graves, large concentrations of charred wheat, barley and lentils were recovered, possibly representing burial offerings or the remains of ceremonial meals. Concentrations of burnt mudbricks were found there as well (Galili et al. 2009).

\subsubsection{Water Wells}

At several PN sites, there were circular structures 1-1.5 $\mathrm{m}$ in diameter, made of undressed stones, representing storage pits and water wells (Galili and Weinstein-Evron 1985; Galili et al. 1997; Galili et al. 2016a). Excavation of the pit fills yielded potsherds, flints and sometimes faunal remains and plant fragments. Cylindrical structures (up to $1.2 \mathrm{~m}$ high) consisting of several courses of undressed stones were found above some of these stone structures at Kfar Galim and Nahal Galim (Fig. 23.16, C). These probably represent the super-structure of water wells. At Kfar Samir, three water wells were found at a depth of $-5.5 \mathrm{~m}$, some $200 \mathrm{~m}$ offshore. They were constructed of alternating courses of wooden beams and undressed stones, mostly limestone pebbles. One (well no. 3) had a rectangular opening $1 \times 0.8 \mathrm{~m}$ and was excavated to a depth of $2 \mathrm{~m}$ without reaching the bottom (Fig. 23.16, A, B). With depth, this well widens and becomes more circular in plan. In its lower part, two courses of 


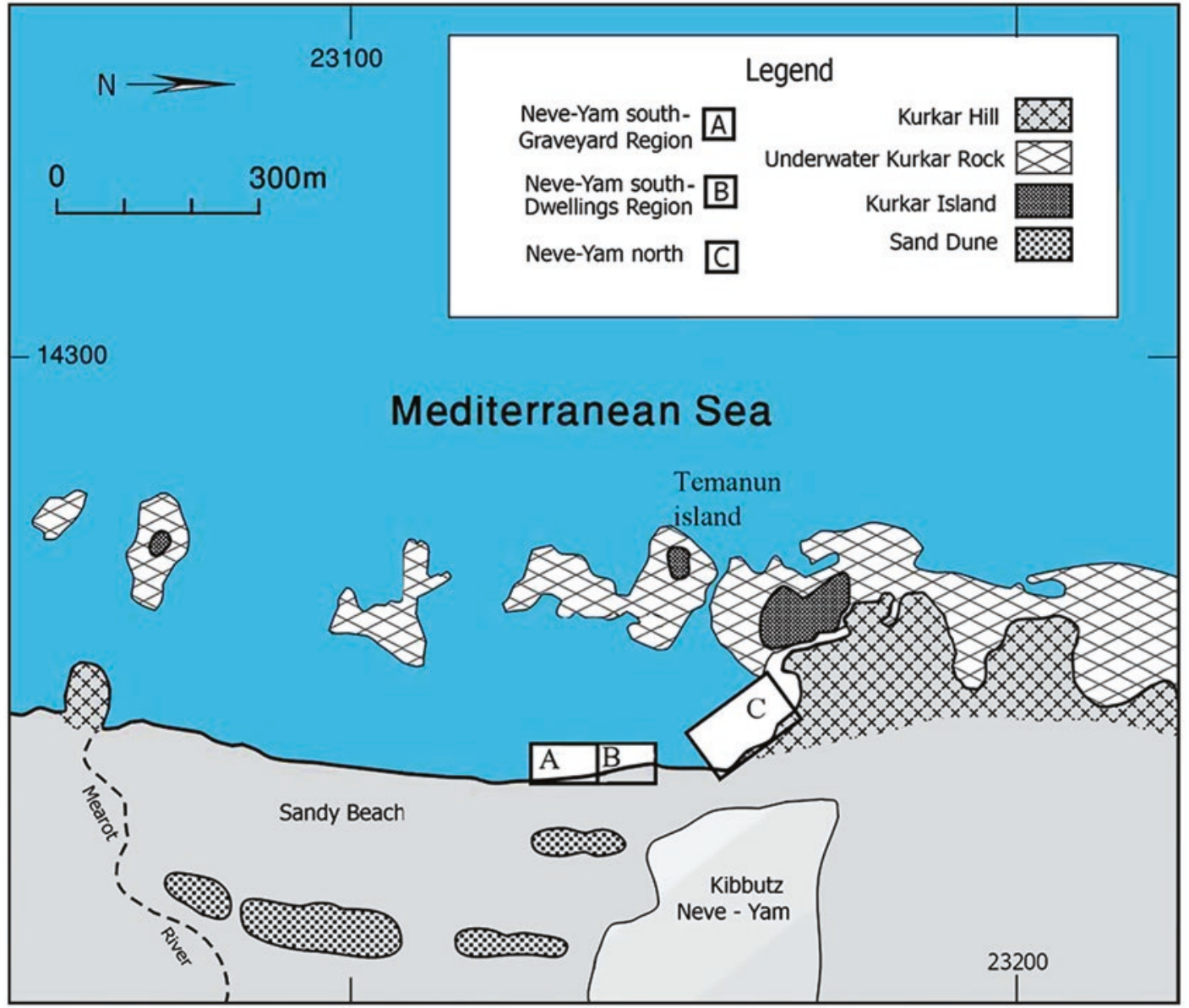

Fig. 23.13 Plan of the Neve-Yam site, showing the separation between the graveyard (a) and the contemporaneous dwelling area of the settlement (b). Also shown are environmental and geomorphological features in the surrounding area. Drawing by Ehud Galili

stones were laid between the wooden beams. The fill consisted of clay, small stones, a few bird bones, olive stones, potsherds, flint flakes and probable straw remains, with a date range of 7964-7320 cal BP (Table 23.2; Galili and Weinstein-Evron 1985; Galili et al. 2018). Similar wells were recovered at Kfar Galim at 2-3 m depth. These wells are some of the earliest known wooden structures in the world.

\subsubsection{Olive Oil Production}

At Kfar Samir central and south sectors, Hishuley Carmel, Tel Hreiz and Hahoterim, concentrations of thousands of olive stones, many of them crushed, were found in fill of pits dug into the clay and are interpreted as representing various stages in the extraction of olive oil (Galili et al. 1989, 1997; Galili and Sharvit 1994-5; Galili and Rosen 2007, 2011a; Galili et al. 2018). At Kfar Samir, a pit paved with stone pebbles and filled with mostly crushed olive stones, was excavated. Large stone basins and basket-work strainers (discussed below) were recovered and are thought to have been associated with the processing of the olives. These finds represent the earliest known evidence for the production of olive oil and an exemplary case of the secondary products revolution. 


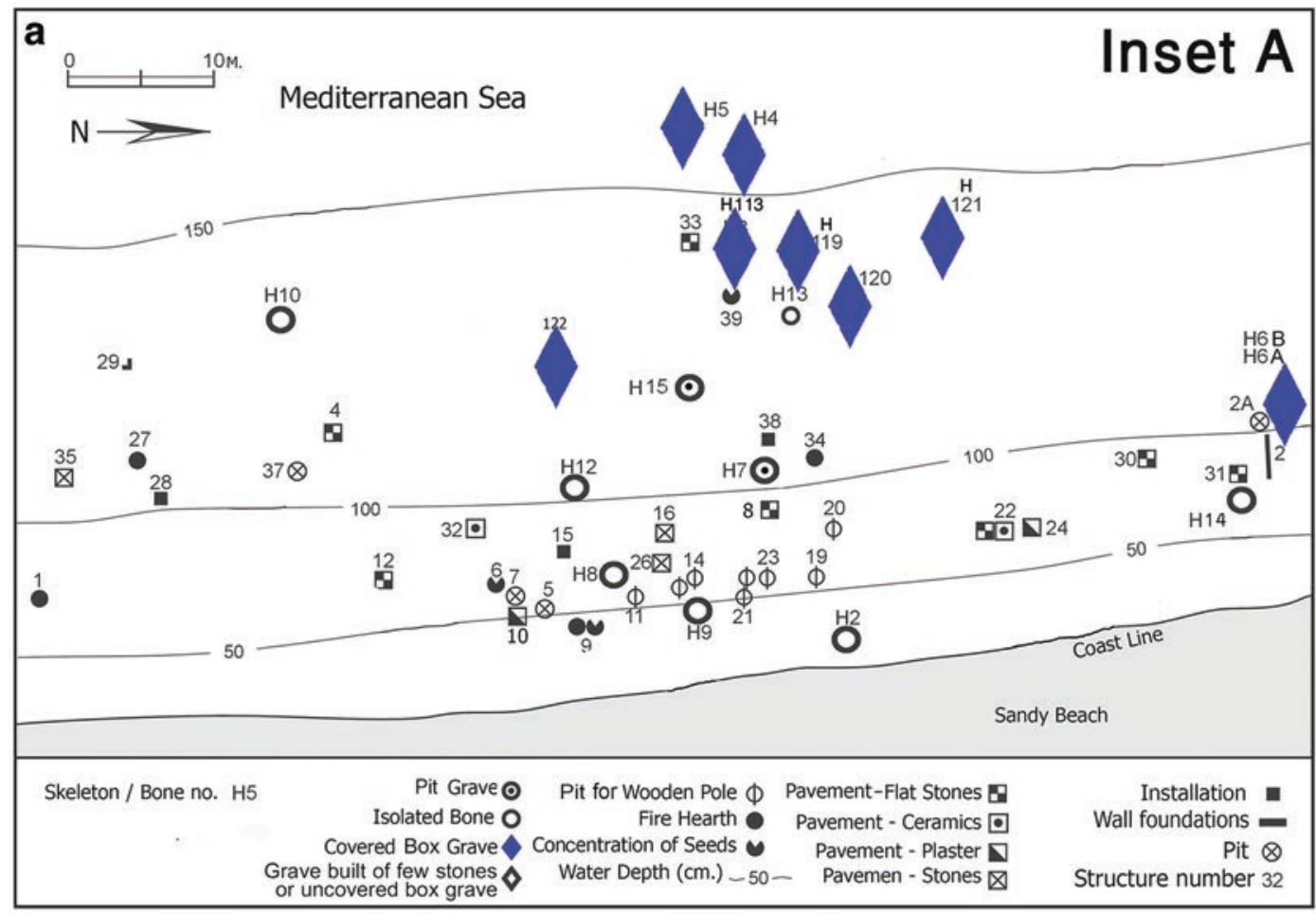

b

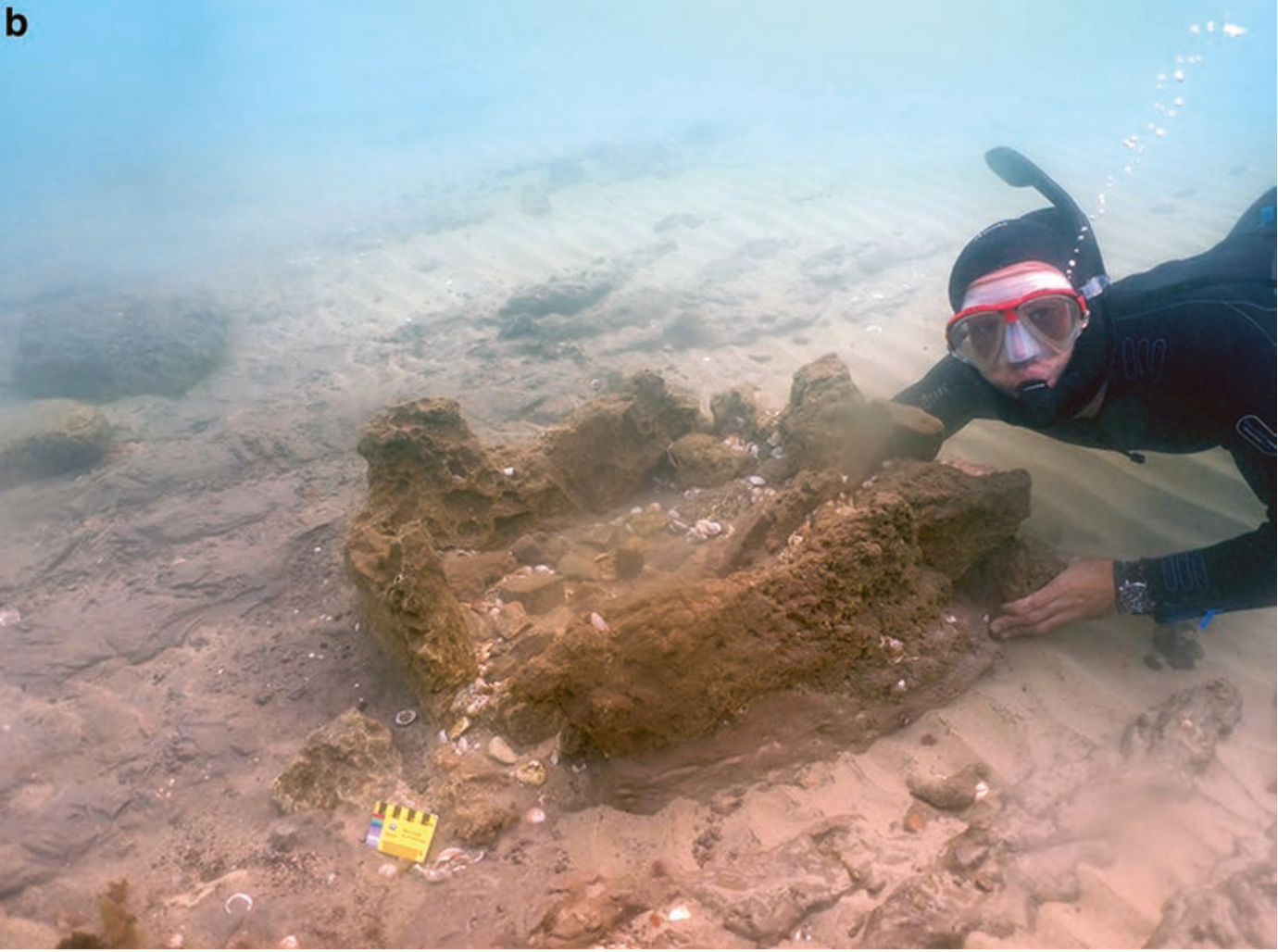

Fig. 23.14 Detailed plan of features in the Neve-Yam graveyard (a), showing graves, storage pits, dwelling and other features. Inset A refers to the areas marked in Figure 23.13. Drawing by Ehud Galili, (b) small stone-built box grave, probably of a child, Photo by Ehud Galili 


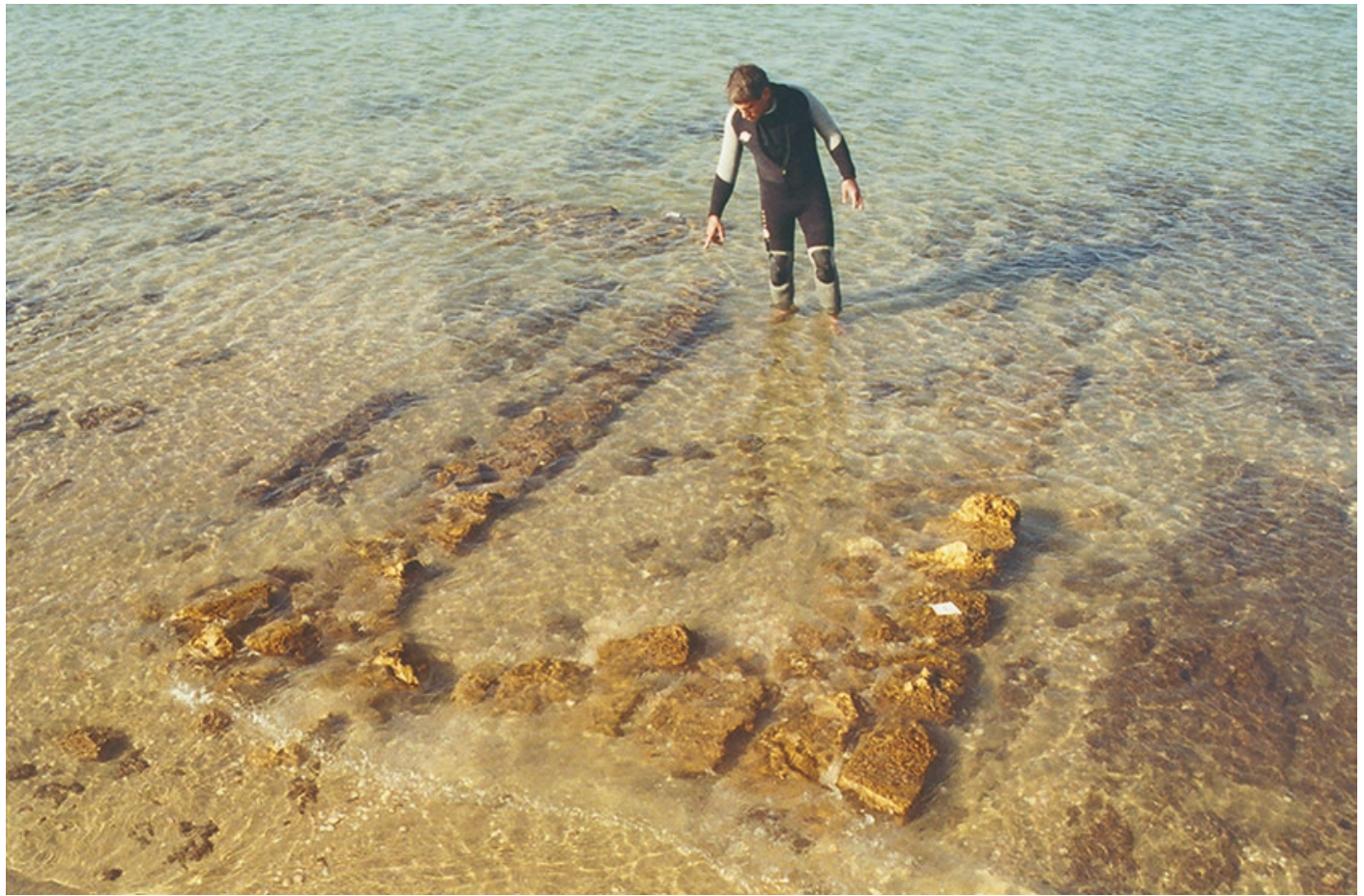

Fig. 23.15 Remains of rectangular stone dwellings at Neve-Yam. Photo by Joseph Galili

\subsubsection{Material Culture}

\subsubsection{Flint, Ground Stone and Pottery}

Flint artefacts include flake tools and polished bifacials (adzes, chisels and axes), sickle blades and additional blade tools. Neve-Yam south had numerous narrow plano-convex chisels, adzes and rectangular backed and truncated sickle blades. Noteworthy in all PN sites is the absence of arrowheads (Galili 2004, pp. 245-255, 438449). Ground-stone artefacts found in all PN sites were made of limestone, sandstone (kurkar) and especially basalt (mortars, grinding stones, chalices, troughs and cup marks). Stone containers are less abundant than at Atlit-Yam, probably associated with the introduction of pottery production. Also, the use of basalt contrasts with PPNC Atlit-Yam, where ground-stone artefacts were made from local materials such as limestone, for delicate small vessels, and kurkar, for large and robust bowls). This difference may reflect greater reliance on crop processing in the
$\mathrm{PN}$, and hence the need for a more durable material such as basalt, as well as more extensive trade ties with the hinterland (Galilee and the Golan Heights) where basalt is found (Galili et al. 1993; Galili 2004, pp. 189-193; 461-462).

The largest pottery assemblage is from NeveYam South, with painted and incised bowls, spouted vessels, hole-mouth jars, bow-rim jars and pithoi, including a sherd decorated with incised fish and a herringbone design (Fig. 23.17; Galili 2004, pp. 172-189 450-460).

\subsubsection{Wooden Artefacts and Basketry}

At Kfar Samir, a complete wooden bowl made from Ceratonia siliqua, the carob tree or $\mathrm{St}$ John's bread and dated to 8275-7872 cal BP was found in a pit (Fig. 23.18: A; Table 23.2; Galili and Schick 1990). The bowl shows evidence of the tools used in its manufacture, with adze or chisel marks on the outer surface, a rougher finish on the interior and the base and the rim smoothed and polished. Pieces of unidentified branches and 

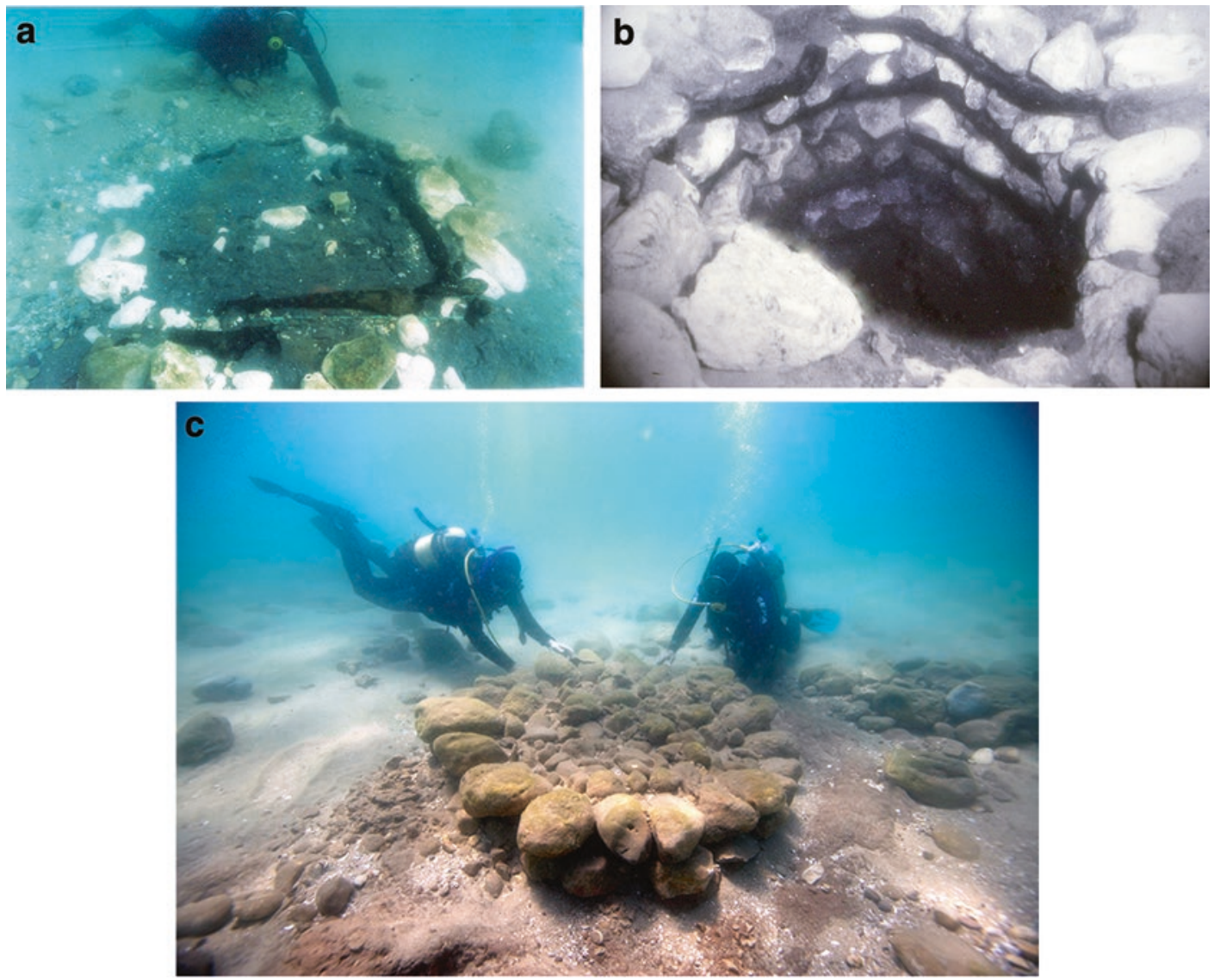

Fig. 23.16 Water-well 3 at Kfar Samir before excavation (a) and after excavation (b). The alternating layers of wooden branches and stones are clearly visible in (b). Photos by Ehud Galili, (c) superstructure of a water well from Nahal Galim, Photo by Itamar Grinberg

straw, perhaps remains of a mat or a basket, were found next to it. A second find from another part of the site is a fragment of a pot-shaped wooden bowl with a flat base, a straight wall, part of the rim and a knob-like handle with a narrow lateral perforation (Galili et al. 2007). In one of the Kfar Galim wells, three sections of wood (each c. $25 \mathrm{~cm}$ long and $15 \mathrm{~cm}$ in diameter) showed cut marks at both ends, suggesting pre-forms intended to produce wooden bowls similar to those described above (Fig. 23.18: B).

At Kfar Samir, a pit $0.9 \mathrm{~m}$ in diameter and $0.55 \mathrm{~m}$ deep was exposed on the sea bed at a depth of $2.3 \mathrm{~m}$, and excavation revealed a fill of grey clay containing dozens of olive stones (Fig. 23.11: B) and pieces of a braided basket preserved by waterlogging (Fig. 23.19: A). The basket was made from stems 3-5 mm thick by the method of 'alternate pair twining' (Galili et al. 1997) and included a round piece, probably the base, and parts of the wall. Because of its association with the olive stones and its similarity to modern basketry items used to strain the oil from pressed olives (Fig. 23.19: B), this item is thought to have been used for a similar purpose. At Tel Hreiz, a woven circular ring of plant material may have been the rim of a basket. Also, at Kfar Samir a unique piece of basketry was found in an unlined pit dug in the upper clay level. After laboratory treatment, it turned out to be a mat, $7 \times 16 \mathrm{~cm}$, made of bundles of unidentified material, perhaps rushes or straw, and constructed using the technique of 
Fig. 23.17 Potsherd with incised fish figures and herringbone designs from Neve-Yam. Photo by Ehud Galili
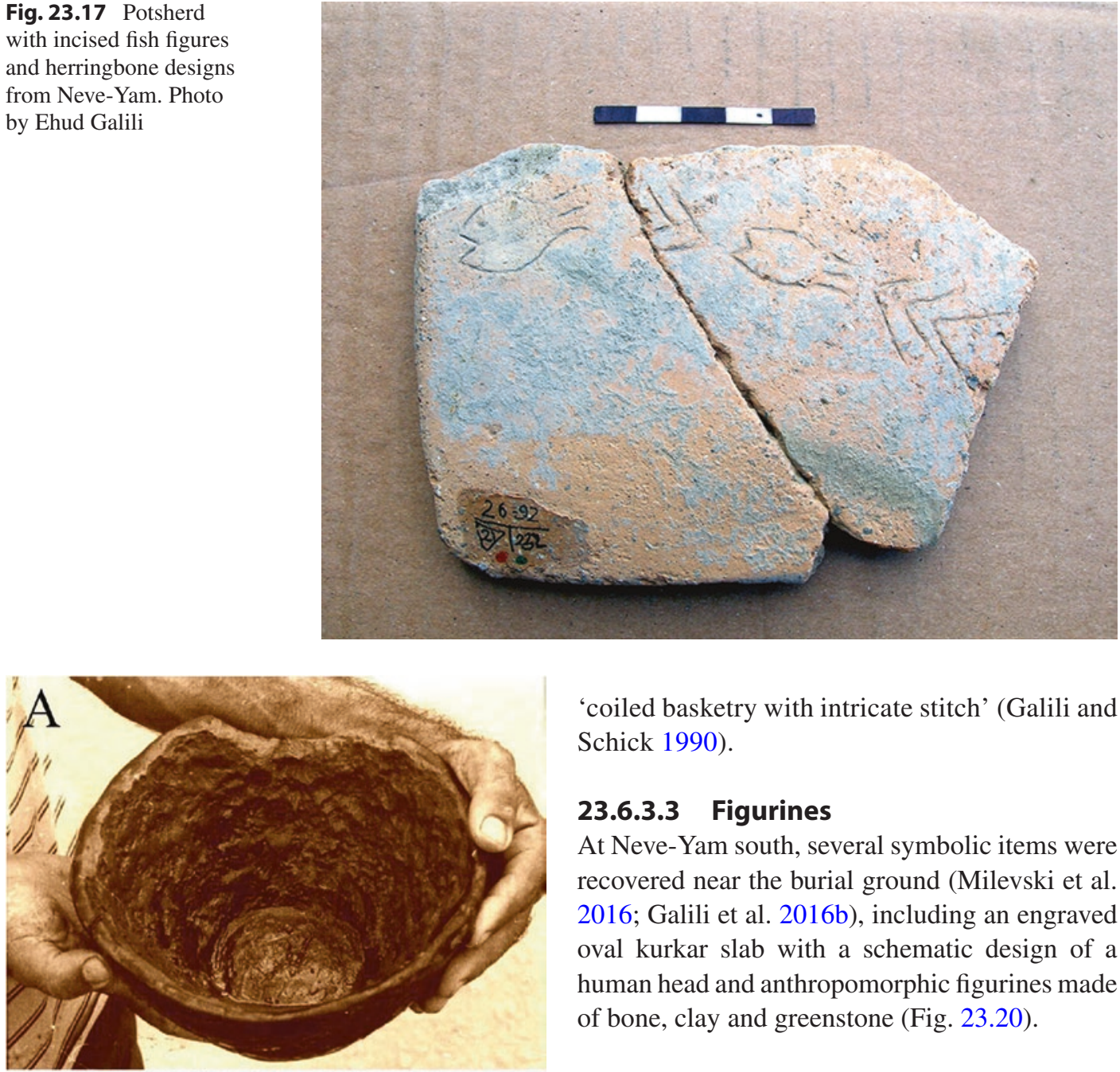

'coiled basketry with intricate stitch' (Galili and Schick 1990).

\subsubsection{Figurines}

At Neve-Yam south, several symbolic items were recovered near the burial ground (Milevski et al. 2016; Galili et al. 2016b), including an engraved oval kurkar slab with a schematic design of a human head and anthropomorphic figurines made of bone, clay and greenstone (Fig. 23.20).

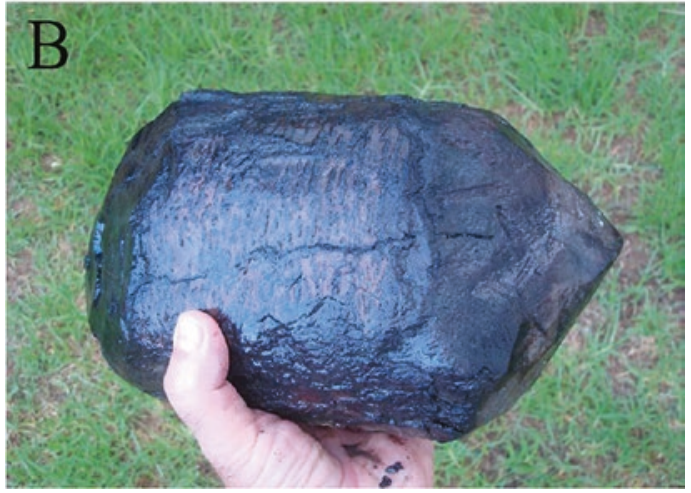

Fig. 23.18 Wooden artefacts from PN sites. (a) Complete bowl from Kfar Samir made from the wood of a carob tree; (b) section of wood from the fill of a well at Kfar Galim, showing cutmarks at both ends, possibly intended for the production of a wooden bowl. Photos by Ehud Galili

\subsubsection{Plant and Animal Remains}

\subsubsection{Plant Remains}

At Kfar Galim and Tel Hreiz, numerous waterlogged plant remains were found, while at NeveYam south, three large concentrations of charred seeds, possibly associated with the burials, were recovered: (1) c. $300 \mathrm{cc}$ of seeds mixed with clay, dominated by domesticated lentils (Lens culinaris var. microsperma) (Kislev et al. 2004), some infested with beetle pests, probably Bruchus sp; (2) c. $100 \mathrm{cc}$ of grains mixed with clay in a hearth built of burnt mudbricks, and dominated by domesticated barley (Hordeum sativum $=H$. vulgares L.), along with several seeds of domesticated emmer (Triticum dicoccum), one seed of 


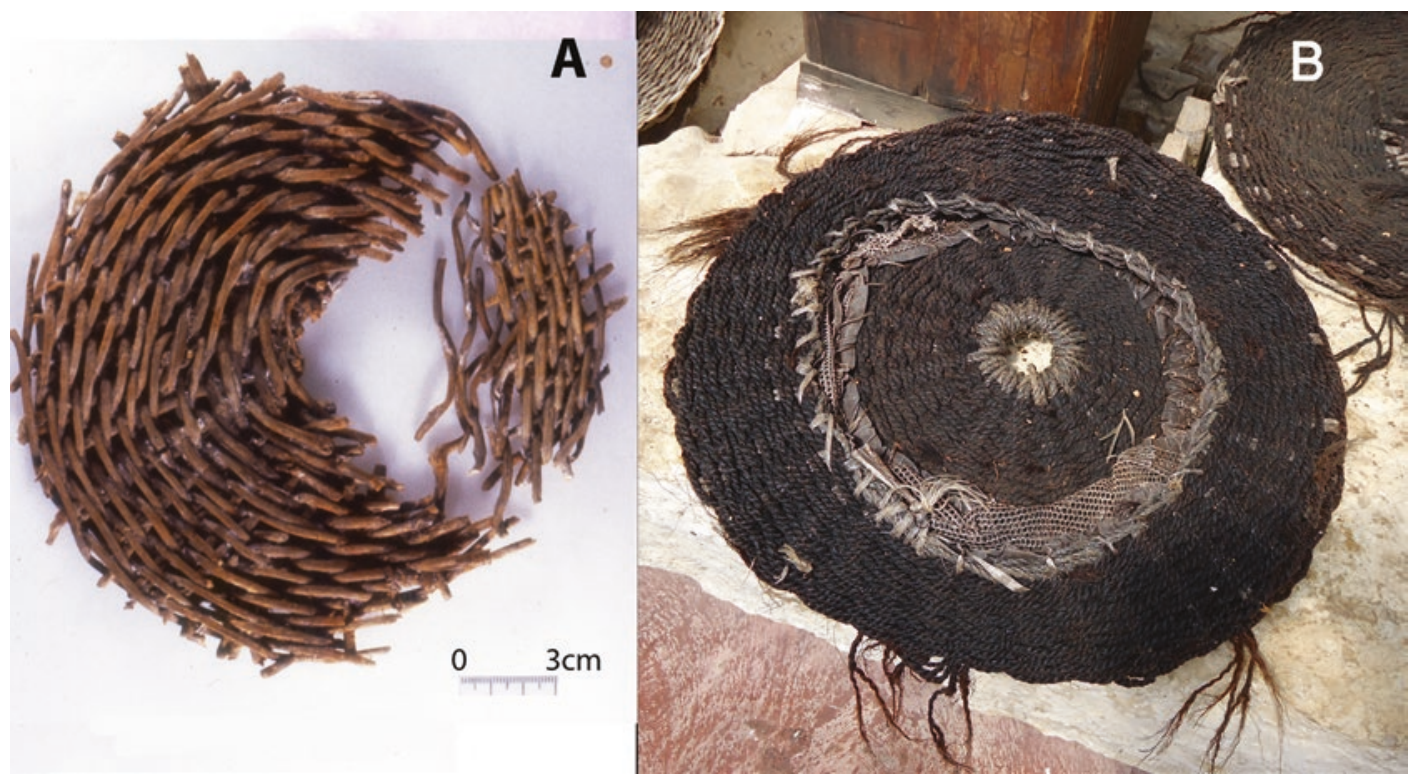

Fig. 23.19 Items of basketry. (a) Archaeological specimen found next to a cache of olive pits; (b) modern item of similar design used as an oil strainer. Photos by Ehud Galili

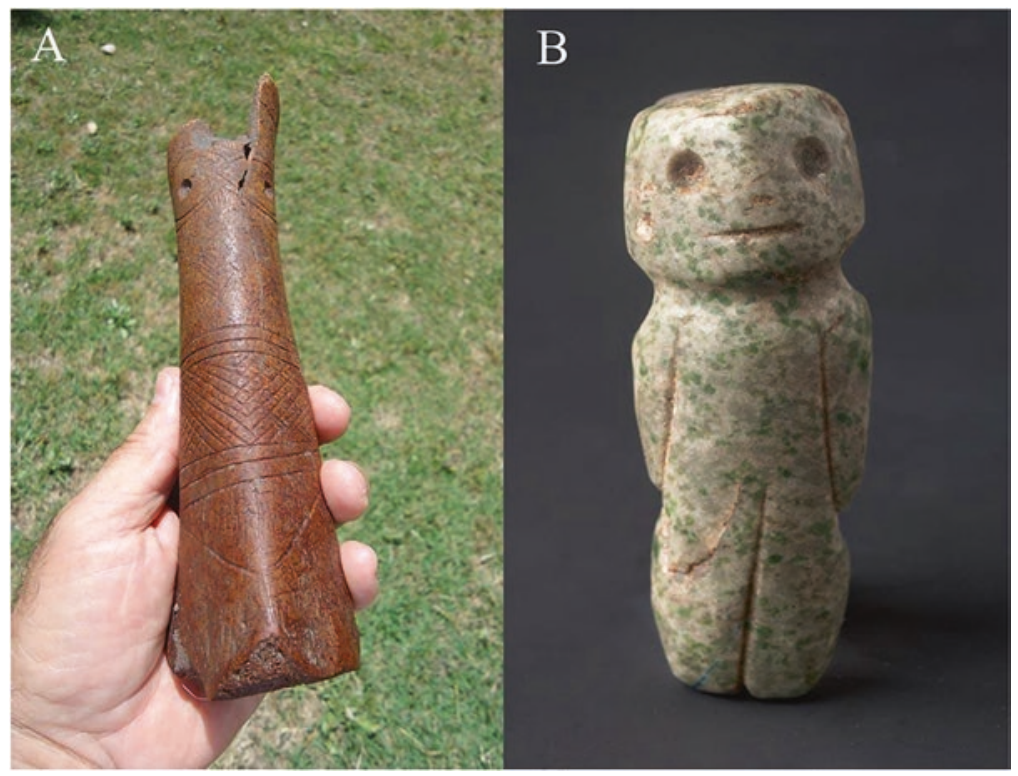

Fig. 23.20 Anthropomorphic figurines from Neve-Yam south. (a) Bone figure with herringbone designs, photo by Ehud Galili; (b) figure made of green stone, courtesy of the Israel Museum

Viciae and a few seeds of Liliaceae; and (3) some $300 \mathrm{cc}$ of seeds consisting of pulses: pea (cf. Pisum vicia narbonensis), vetch (Lathyrus sect. cercula), horse bean (Vicia faba var. minor), len- til (Lens culinaris var. microsperma), along with domesticated flax (Linum usitatissimum) and a few wild plants or weeds (Galium, Lolium and Lilicaeae) (Galili et al. 2018). 


\subsubsection{Animal Remains}

At Neve-Yam and Tel Hreiz, and to a lesser extent at Kfar Galim, faunal remains are abundant, indicating the dominance of domestic animalssheep, goat, cattle and pigs, with only a few remains of wild species-gazelle (Gazella sp.) Persian fallow deer (Dama dama mesopotamica), Eurasian badger (Meles meles), possibly also wild boar (Sus scrofa ferus) and wild birds, attesting to ongoing trapping/hunting as a minor subsistence activity. Isolated remains from the other sites include mallard duck (Anas platyrynchos) and the Palestine molerat (Spalax ehrenbergi) (Horwitz et al. 2002, 2006). Remains of dog (Canis familiaris) are notable at Tel Hreiz and Kfar Galim. Butchery marks indicate that animals were processed and consumed on-site using a variety of stone tools; kill-off patterns of goats are dominated by immature animals, indicating an emphasis on meat (Greenfield et al. 2006). Fish bones are present at Kfar Galim, Tel Hreiz and Neve-Yam south but are few-mostly Sparidae, Serranidae and the freshwater Tilapia sp. This scarcity is a notable contrast to AtlitYam but may indicate only that fish bones are underrepresented because bones at the PN sites were collected by hand without the use of sieves.

\subsubsection{Human Burials}

Human remains were found at Neve-Yam and Tel Hreiz. Most of the skeletal remains consist of primary in situ burials, while some were represented by scattered bones, most likely due to postdepositional disturbance of burials. At Tel Hreiz, two disturbed burials were recovered in pits dug in the clay. Additionally, two stone-built cists $(0.6 \times 1.3 \mathrm{~m})$ built of stone slabs probably represent graves but have not been excavated. Eleven in situ human burials were excavated at Neve-Yam south, concentrated in a relatively small area $(40 \times 70 \mathrm{~m}$; Galili et al. 2009). Eight are stonebuilt graves, some partially eroded by the sea, consisting of an oval burial chamber lined with undressed stones, covered by stone slabs and with an east-west orientation (Fig. 23.13: B;

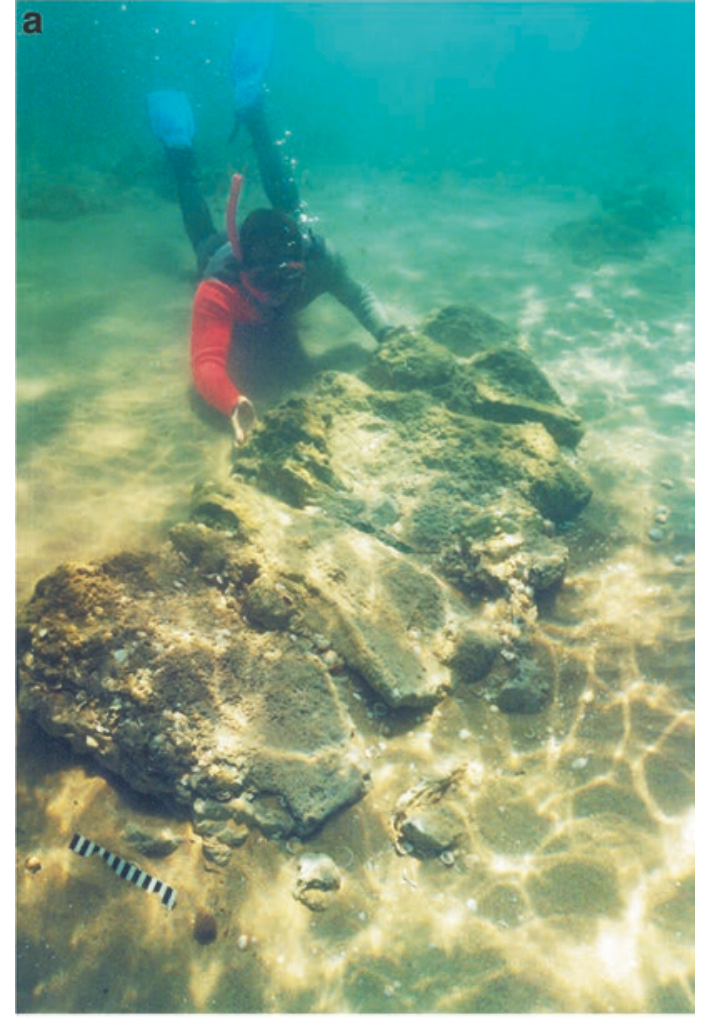

b
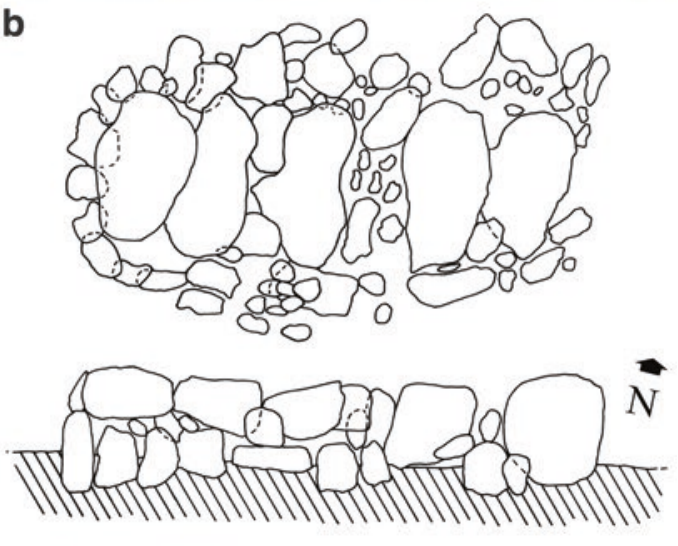
$50 \mathrm{Cm}$

Fig. 23.21 Stone-built cist grave at Neve-Yam. (a) As it appeared on the sea bed; (b) plan. Drawing and photo by Ehud Galili

Fig. 23.21). Three others are in simple pits dug in the clay, while traces of four additional individuals are represented by scattered remains. Four skeletons were fully flexed, and four partially flexed. Six additional stone-built cist structures, most 
probably graves, were found at the site but not excavated. The estimated number of individuals at Neve-Yam is 15 (Eshed et al. 2004; Eshed and Galili 2011), including those represented by isolated or scattered remains, comprising eight children ( $0-10$ years), one adolescent (10-18 years) and six adults ( 1 female, 3 males, 2 indeterminate). Oblique tooth wear in one individual suggests use of the teeth as tools (Eshed et al. 2010). No grave offerings were recovered, but nearby hearths, paved surfaces and concentrations of charred seeds may indicate activities such as ceremonial meals associated with the burial rite.

In addition, a primary burial of an infant (1-2 years old) was found on the Temanun Island (Octopus Island), an islet c. $140 \mathrm{~m}$ from the coast opposite the submerged site of Neve-Yam and was associated with possible grave goods-a broken pottery vessel with an elongated nozzle and a flint flake (Galili et al. 2016c). At the time of the burial, the islet was a kurkar hill on the shoreline (Fig. 23.22).
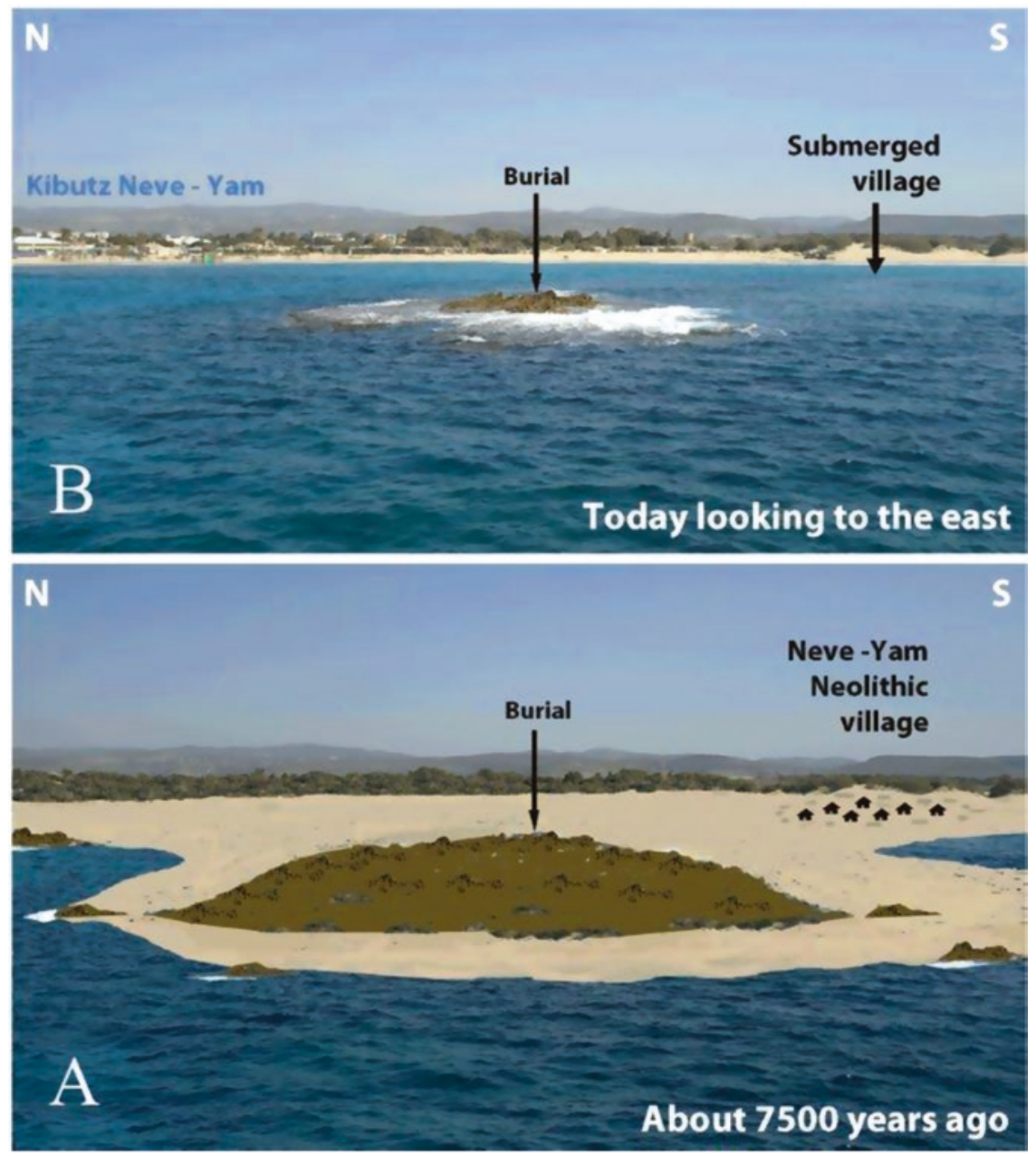

Fig. 23.22 View of the burial site on Temanun Island looking towards Neve-Yam. Upper (b): the present day; lower (a): reconstruction at the time of burial. Photos and reconstruction by Ehud Galili 


\subsection{Discussion}

The submerged Neolithic villages off the Carmel coast have revealed a wealth of new data on the Pre-Pottery and Pottery Neolithic/Chalcolithic period of the region. In some respects, the finds are no different from what has been found in terrestrial sites of the same period-a similar range of flint artefacts, ground-stone tools, ornaments, figurines and ceramics, faunal remains and structures made from undressed stone or mudbrick. In other respects, these sites highlight features that are uniquely the result of the original site location close to the shoreline and to subsequent submergence by sea-level rise and the conditions of underwater preservation. The recovered evidence is not only unusual in preserving organic materials that would not normally survive in terrestrial deposits, but also in the quantity, variety and excellent preservation of other materials and features.

This evidence includes the use of wood in structures and for making artefacts; the construction of stone-lined and stone- and wood-lined water wells, which also provide good index points for measuring sea-level change; large numbers of human graves with well-preserved skeletal remains providing unusually rich details of burial practices, palaeodemography and health; stone-built dwellings and other structures, which together with the locations of graves show the wider layout of the settlement including evidence in the PN period of a separately demarcated burial ground; generally good preservation of bone; and the survival of a wide range of plant remains.

\subsubsection{Water Wells and Sea-Level Change}

The wells are of special interest not only for the details of their construction and their contents but also as evidence that already in these early periods people were able to improve the water supply by creating an artificial, permanent source of water. In a region where water is a limiting factor on the duration of human habitation, this technological development would have been an important contribution to sustaining permanent settlement in one place and to improving the reliability of the subsistence economy.

In addition, the wells provide valuable additional information on sea-level rise, palaeoenvironment and human adaptation to the changing coastal environment. The natural slope of the groundwater table on the Israeli coastal plain is about 1:1000 (Kafri and Arad 1978), and studies of numerous wells of all periods show that excavation about $0.5 \mathrm{~m}$ below the water table provides a sufficient column of fresh water (Nir and EldarNir 1986, 1987, 1988). By combining these two parameters with the depth below modern sea level at the base of the Neolithic wells, it is possible to estimate the sea-level position when they were in use and the distance of the site from the coastline. The PPNC Atlit-Yam well bottom is about $15.5 \mathrm{~m}$ below modern sea level, indicating a sea-level position of c. $-16 \mathrm{~m}$. By the same method, the later PN well at Kfar Samir gives a sea-level position of c. -7 to $-9 \mathrm{~m}$ (Galili et al. 1988, 2005a).

Combining these estimates with other natural and cultural indicators of sea level, such as wavecut notches, abrasion platforms, maritime installations and clusters of anchors originating from shipwrecks, it is possible to reconstruct a general, estimated, sea-level curve (Fig. 23.23; Galili et al. 2017a;). This sea-level curve, in its turn, can be combined with bathymetric and geological maps to reconstruct changes in coastline configuration (Fig. 23.24; Galili et al. 1988, 2005a).

The curve shows how sea level has risen progressively and continuously from a depth of nearly $-40 \mathrm{~m} \mathrm{10,000}$ years ago. It continued to rise during the occupation of Atlit-Yam and the PN sites at a rate of 11-13 mm per year. About 6500 years ago, the rate of rise slowed to c. 2.5$3.5 \mathrm{~mm}$ per year, reaching the modern level during the Middle Bronze Age at about 4000 years BP. The maps show how the coastline at the beginning of occupation at Atlit-Yam was some $1.5-2.5 \mathrm{~km}$ west of its present position and consisted of an indented waterline with bays and 
Fig. 23.23 Estimated SL curve for the past 10,000 years on the Carmel coast as indicated by archaeological and geomorphological SL markers: (1) terrestrial clay palaeosol; (2) Atlit-Yam water wells; (3) Kfar Samir water well; (4) Kfar Samir dwellings; (5) MiddleBronze Age (Byblos Type) stone anchors; (6) erosion platforms and wave-cut notches; (7) Roman-Byzantine rock-cut features. Drawn by Ehud Galili

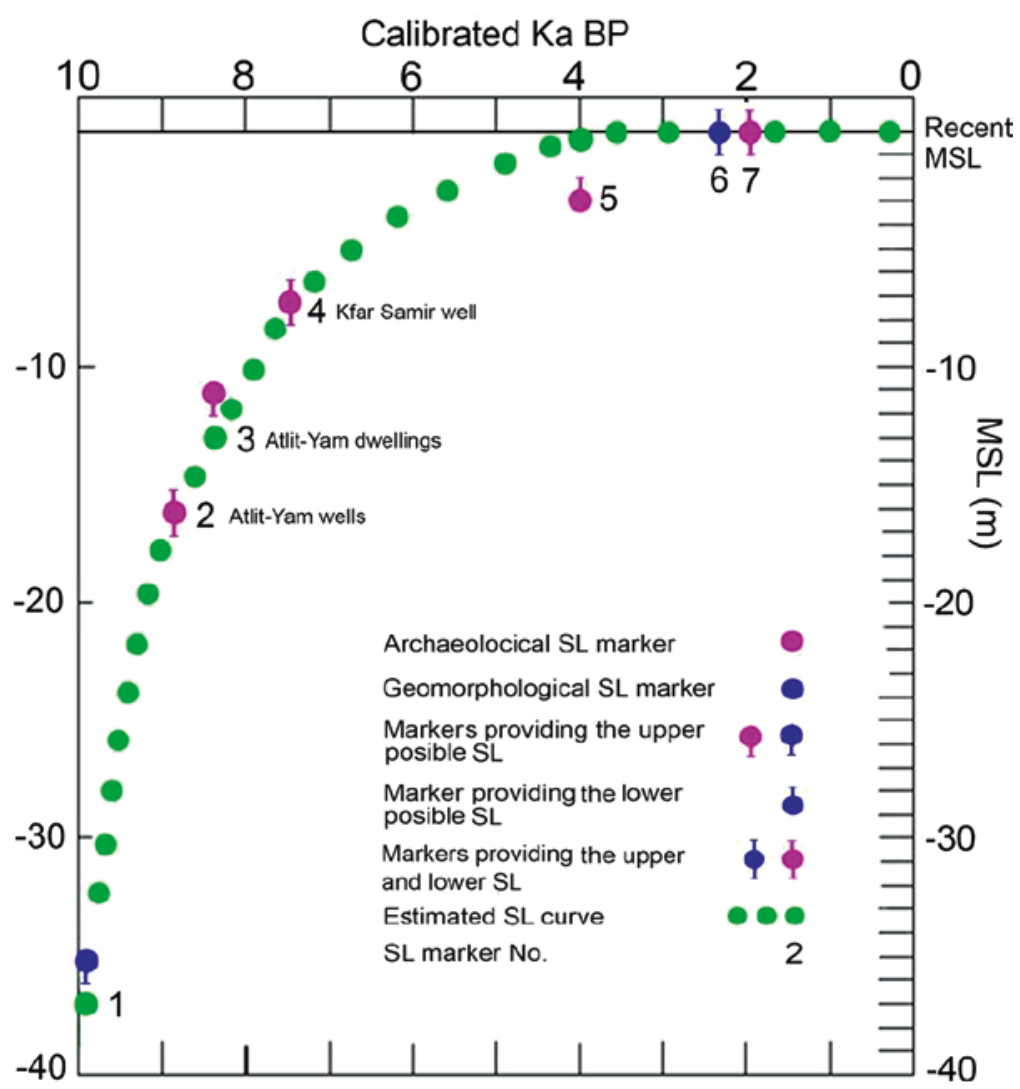

lagoons (Fig. 23.24). In the later period during the subsequent PN period, sea-level rise created a smoother sandy shoreline with a series of small offshore islands. These too disappeared shortly afterwards with continued sea-level rise creating a coastline configuration much as today.

The relatively rapid rise of sea level during the occupation of the Neolithic sites must have caused ongoing problems and required active human adaptation to the changing conditions. These would have begun with progressive salinization of the water wells. According to the evidence of well 11 at Atlit-Yam, initially the occupants tried to counter this tendency by putting rocks and other materials in the bottom of the well in an attempt to exploit the upper, less saline part of the water table. Eventually, the well fell out of use and was used as a rubbish pit. Finally, with further sea-level rise, the whole settlement was abandoned. Pareschi et al. (2006, 2007) have suggested that a tsunami associated with the eruption of Mount Etna caused the abandonment of Atlit-Yam. But there is no evidence of tsunami deposits, nor of sudden and catastrophic changes such as damaged structures, whole animal carcases or evidence of traumatic injury, such as might be expected to result from a tsunami event (Galili et al. 2008). The slow and inexorable rise of sea level provides a sufficient explanation for progressive change in site use and eventual abandonment, while such damage as is present can be accounted for by the postdepositional effects of marine erosion.

\subsubsection{Burial Customs}

The large number of burials makes it possible to chart changes through time and adds new information to what is already known from contemporaneous sites elsewhere in the Southern Levant. For example, the Atlit-Yam site shows similari- 


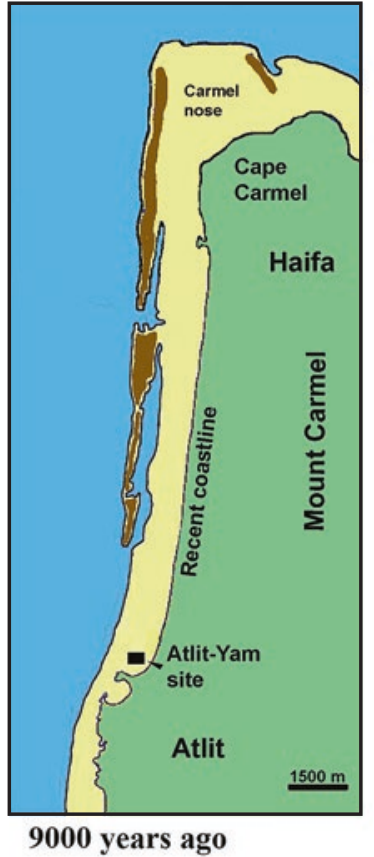

Recent land

Palaeo island

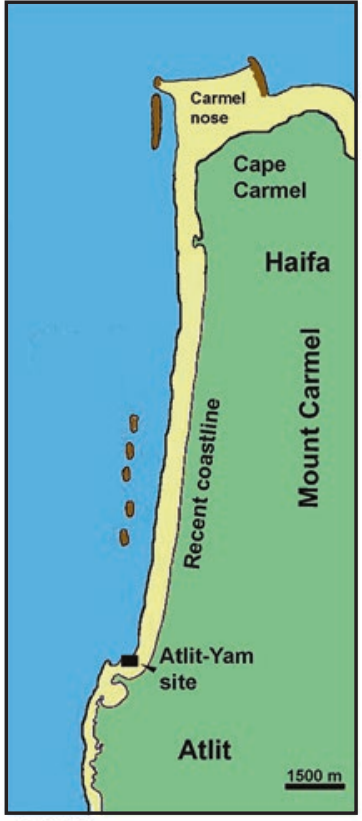

8000 years ago

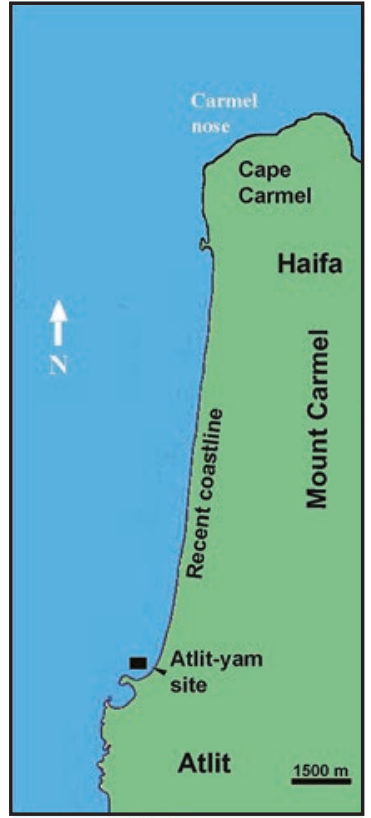

Today

Submerged landscape

\section{Currently submerged} kurkar ridge

Fig. 23.24 Reconstruction of changes in the shoreline configuration of the Carmel coast over the past 9000 years. Drawn by Ehud Galili

ties in burial practices to the terrestrial PPNC site of 'Ain Ghazal in Jordan (Galili et al. 2005b; Eshed and Galili 2011). However, Atlit-Yam is unique in the large number of primary burials and the grave goods deposited with the dead, including flint axes and ground-stone items. Also, the extensive layout shows that the burials are widely distributed across the site-in open spaces between dwellings, close to walls and occasionally inside structures. By the time of the PN period, Neve-Yam and Tel Hreiz show evidence of burials in stone cist-like graves, a feature that is lacking at Atlit-Yam and other PPNC sites.

Similar graves are known from PN sites in the wider region such as Byblos and Tabaqat Al-Buma (Stekelis 1972; Dunand 1973; Banning 1995). However, Neve-Yam shows a new feature not previously recorded at any other PN site in the region, and that is the organisation of space within the settlement to achieve a clear separation between the areas of domestic activity and an area reserved for burials. This feature of a separate graveyard, containing stone-built cist graves in an organized pattern, is an innovation of the Wadi Rabah culture. It may have resulted from intensive soil-disturbing activities (planting, digging wells and foundations of structures) associated with long-lasting sedentism, agriculture and the burying of the dead, provoking competition for limited subterranean space and the need to resolve the conflict between the needs of the living and the needs of the dead (Galili et al. 2009, 2017c). 
Fig. 23.25 Comparison of male mortality patterns at Atlit-Yam with Neolithic sites in the southern Levant. Drawing by Vered Eshed

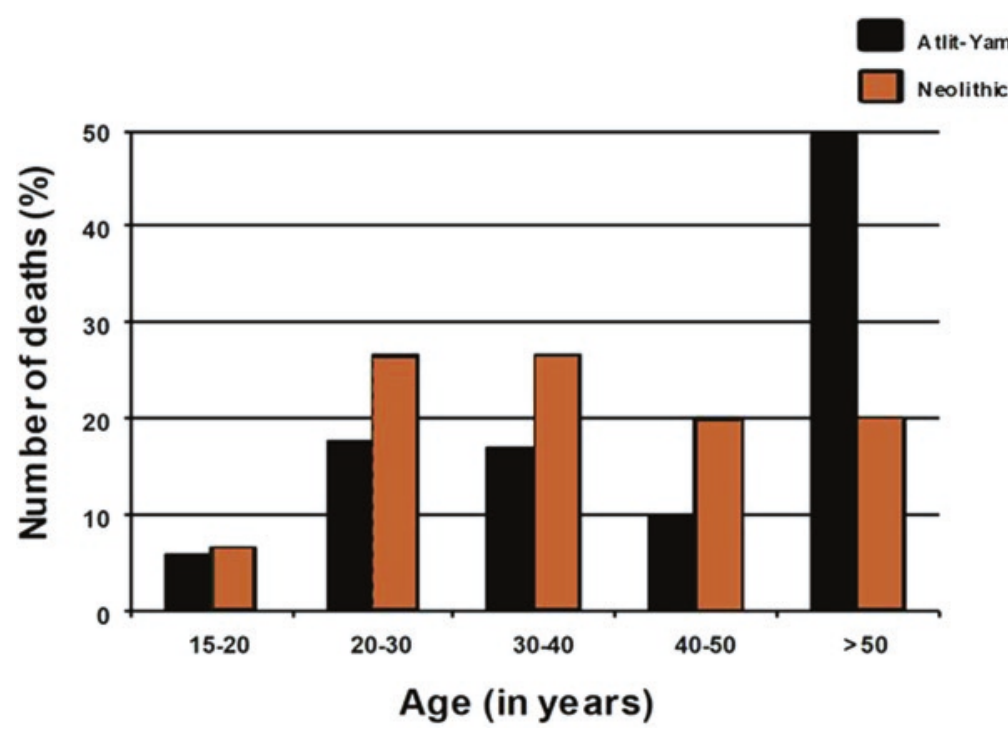

\subsubsection{Palaeodemography and Health}

The large sample of human skeletal material made available from the many burials at these underwater sites and the generally excellent bone preservation have enabled a comparison of mortality profiles and produced evidence of pathologies indicating the presence of infectious diseases. The mortality pattern of the Atlit-Yam male population shows greater longevity than males in the PN and greater longevity than inland PPN populations (with higher mortality values in the over 50-year age cohort) (Fig. 23.25; Eshed and Galili 2011). This can be attributed to a balanced nutrition resulting from the more stable and varied food supply available to the inhabitants of Atlit-Yam and their access to marine resources, compared to their inland contemporaries. This is also consistent with indications that marine resources were less intensively exploited or less abundantly available along the Carmel coastline during the PN period.

Evidence of infectious diseases includes the presence at Atlit-Yam of the oldest known record of tuberculosis, and of thalassemia, a mutation that makes people less susceptible to malaria, and may reflect their adaptation to the malariainfested coastal environment (Hershkovitz et al. 1991). Malaria is an infectious disease typically associated with mosquito-infested marshes and wetlands in coastal regions and continues to be a major health concern at the present day (Learmouth 1977; World Health Organization 2017). Malaria may also be tied to the increased population density associated with sedentary agriculture (Smith and Horwitz 2007; Eshed et al. 2010) and to the intensified construction of water wells and pools of standing water within, or close to, the settlements.

\subsubsection{Organic Preservation}

The wide range of organic remains preserved on these sites is perhaps their most distinctive feature, and the one feature, more than any other, that demonstrates the unique conditions of preservation in underwater settlements. Foremost are the botanical remains - wood, plant fibres, twigs, reeds and seeds. These demonstrate the use of wood as a building material and in the manufacture of artefacts such as bowls and basketry. The recovery of seeds and other plant materials extends the range 
of known edible plants foods, including evidence for the production of olive oil and collection of plant material for animal fodder.

These preservation conditions also apply to the animal bones, and although these can be found in terrestrial sites, underwater preservation has ensured their recovery in abundance and for the most part in excellent condition with minimal evidence of post-depositional abrasion facilitating extensive documentation of modifications including butchery and tool marks. These assemblages demonstrate the diversity of animals exploited, mostly the farmyard domestic animals but with a small element of hunting of wild animals such as fallow deer and gazelle, and a significant representation of fish at Atlit-Yam and perhaps also at the later PN sites although fish bones may be under-represented in the latter because of the recovery methods used. The condition of the bones and plants has also facilitated biometric and morphological studies, and these, together with the time span represented by the different sites and deposits, have demonstrated a transition from wild to domestic forms. The animals represented by bones from the surface collections at Atlit-Yam, which are the earliest deposits, resemble their wild progenitors, whereas the bones from the Atlit-Yam wells, which represents the last phase of occupation at this site, and from the PN sites, are all fully domestic forms.

\subsubsection{The Mediterranean Fishing Village and Diet}

One of the most interesting revelations to emerge from these investigations is the demonstration of a hitherto completely unsuspected and unrecorded maritime component to the earliest development of animal and plant domestication in one of the world's major centres of agricultural origins. The Levantine and south-eastern Turkish seashores are the closest coastal environments to the inland core areas of animal and plant domestication. At the end of the tenth millennium BP, a mixed mode of subsistence that included crop cultivation, animal husbandry and marine fishing evolved among inhabitants on the Levantine coast, as evidenced by the material recovered from Atlit-Yam (Galili et al. 2002, 2004). Hints of a similar pattern are present at Ashkelon on the southern Israeli coast (Perrot and Gopher 1996; Garfinkel and Dag 2008) and at Ras Shamra on the Syrian littoral (Van Zeist and Bakker-Heeres 1984; Helmer 1989). The presence of such a mixed mode of subsistence at Atlit-Yam fits many of the criteria outlined by Butzer (1996) as characteristics of a typical Mediterranean diet. During the eighth millennium cal BP, olive oil extraction was added to the economy of the PN sites on the Carmel coast (Galili et al. 1997). The subsistence of these PN settlements was characterized by increased reliance on farming and animal husbandry, reduction in the exploitation of marine resources and hunting and intensive use of secondary animal products (milk products, wool fibres). Later still, during the sixth millennium cal BP, more cultivated plants were introduced, such as the domesticated grape, which enabled the production of wine in the Levant (Zohary and Hopf 2000). By 5000 cal BP, what is today commonly termed 'the typical Mediterranean diet' as defined by Butzer (1996) was fully developed.

Examining the seasonality of the different subsistence activities in Atlit-Yam in different months over the year (sowing, harvesting, animal husbandry, gathering and fishing) demonstrates that it was possible to efficiently combine landbased food procurement activities with the exploitation of marine resources, with minimum overlap of the essential activities. Together with the invention of artificial permanent sources of water (water wells), these diverse year-round food procurement activities made seasonal mobility unnecessary and enabled a sedentary year-round occupation on the coast (Galili et al. 2004).

The development of the Mediterranean fishing village during the transition to a fully fledged agricultural economy is of great importance and raises a number of further questions: the significance of marine and coastal resources in helping to support year-round sedentism and the develop- 
ment of sedentary agriculture; the question of how widespread this phenomenon may have been on other coastlines adjacent to other centres of plant and animal domestication in the Levant and Anatolia; and the role of such coastal economies in promoting the dispersal of agricultural economies further westwards around the Mediterranean Basin (e.g. Galili et al. 2002).

\subsubsection{Preservation Conditions, Exploration Methods and Future Challenges}

Remaining questions concern the reasons for why so much of the evidence of these settlements has survived the potentially destructive impact of wave action and marine currents, why such a concentration of evidence has been preserved and discovered on this one short stretch of coastline in northern Israel and what the prospects are for the discovery of similar evidence elsewhere or at greater depth.

The factors that have contributed to the preservation and discovery of so much evidence in northern Israel can be summarised as follows:

(1) Many of the features were dug below the surface when the site was in use-human burials, well shafts, storage pits, dwelling foundations-ensuring protection from the worst destructive effects of waves and marine currents as the sea rose over the abandoned settlements.

(2) Accumulations of sediment fill in some of these sub-surface features, such as well shafts, during the lifetime of the settlement, ensured rapid burial and additional protection of discarded artefacts and organic remains.

(3) Rapid accumulation of protective sand covered many sites before they were inundated by sea-level rise and protected them before material could be washed away or destroyed.

(4) Use of stones in the building of structures and the lining of wells and graves provided added protection from, or resistance to, water damage.

(5) Further accumulation of thick deposits of marine sand, once the sites had been inundated, further sealed and protected them until exposed to discovery by partial removal of this sand cover in recent times.

This last factor probably accounts for the particular concentration of sites on the Carmel coastline, as emphasised at the beginning of this chapter, with a sand cover that was neither too thin to act as a protective cover nor too thick to be easily removed by storm action to expose the underlying land surface. Elsewhere, conditions are different. In Haifa Bay, for example, there are extensive palaeolandscapes that are covered with layers of sand up to $20 \mathrm{~m}$ thick. Preserved settlements that have never been exposed may exist below this sand cover. Conversely, on a rocky land surface, such as the 'Carmel nose' plate and off the Galilee coast, sites are likely to have been exposed to marine erosion and destructive postdepositional processes, and what remains is likely to be harder to identify because of marine fouling and biogenic rock growth. In central and southern Israel, the kurkar rock is poorly consolidated and fragile, resulting in considerable erosion, coastal retreat and the creation of coastal escarpments and cliffs tens of metres high (Galili and Zviely 2018). This means that any coastal Neolithic or earlier settlements that were present in these regions would have been vulnerable to destruction during sea-level rise.

Other locally variable factors are the relative attractiveness of the peri-coastal environment for permanent settlements. The presence of palaeosols between the kurkar ridges and the accessible aquifer of high groundwater close to the shoreline may have been a particular attraction on the Carmel coast, especially for societies dependent in part on agriculture.

Whether similar archaeological evidence has survived on earlier palaeocoastlines at deeper levels is unclear. It is not only the logistics of investigating the sea bed that escalate with increasing depth. As discussed in Galili et al. 
(2017a, c) and Galili (2017), the length of time that palaeocoastlines were exposed as dry land, before being inundated again by subsequent sealevel rise, decreases with increasing depth, reducing the length of time available for material to accumulate in one place to create a visible archaeological site. Also, the cultural material deposited as one goes farther back in time is likely to consist of less easily detectable traces of human activity, such as scatters of stone tools associated with temporary hunting camps. In addition, conditions for preservation or visibility are likely to be poorer because of more prolonged exposure to marine erosion on the sea bed.

Experience on the Carmel coast suggests that the most productive approach to site discovery is to concentrate on water depths of 1-15 $\mathrm{m}$, where the thickness of the sand cover provides the optimum compromise between protection and exposure of the underlying land surface, and to follow up chance exposures in the most promising areas with systematic underwater survey and excavation. Sometimes the fringes of such sites can be identified on the shore edge, and some of the underwater settlements, notably Neve-Yam and Tel Hreiz, were first discovered in this way (Wreschner 1977a, b, 1983; Ronen and Olami 1978; Olami 1984). Survey and excavation have therefore been concentrated in the first instance along the shoreline and in shallow water, with regular monitoring for erosion of sand cover, especially after storms. This Israeli model for discovering and studying submerged prehistoric settlements (Galili et al. 2019a) has proved very successful in the past, and it is likely that more remains will be discovered along the coastline of Israel. In terms of future management, priority should be given to searching for exposed and disturbed sites in these shallow areas, not only because of the likelihood of site preservation and discovery there but because these are the areas most vulnerable to natural and human-related destructive activities and most in need of protection or salvage work.

As for the discovery of settlements of similar age on other coastlines further afield, that will depend on whether similar conditions of site pro- tection and exposure are present, and of course on regular monitoring of the offshore environment and the development of underwater methods of investigation similar to the practices that have been developed in Israel over the past 40 years.

\subsection{Conclusion}

The underwater Neolithic settlements of northern Israel provide a striking example of the sorts of evidence that can be preserved underwater and the ways in which that evidence can reveal quite different and unexpected information about coastal adaptations and early developments in social organisation, subsistence economy and technology. The Carmel coast sites have produced some of the earliest evidence in the world for the digging of water wells, the production of olive oil, technology based on the use of wood in building construction and artefact production, sedentary settlements based on a combination of fishing and early developments in plant and animal domestication and details of burial practices including early evidence for the organisation of space within settlements to create separate graveyards. Moreover, most of this evidence owes its survival to the conditions of preservation and discovery afforded by submergence underwater and protection by marine sediments and to the existence of settlements on, or close to, an ancient shoreline at a time when sea levels were lower than present. Little of this evidence would have any chance of being preserved in terrestrial deposits on the present-day land surface or in the hinterland. However, the evidence also demonstrates that the attractions and benefits of living in a shoreline location, notably a more diverse and stable food supply capable of supporting sedentary settlements, came at a price. That price was increased exposure to malaria, and the threat of inexorable sea-level rise, which altered the ecological conditions of the marine environment, caused progressive salinization of the water supply and ultimately forced the abandonment of the settlements. 


\subsection{Management of the Underwater Cultural Heritage}

The Israel Antiquities Authority is in charge of the protection and management of Israeli cultural heritage, including underwater antiquities.

Acknowledgments We wish to thank the EU through COST Action TD0902 SPLASHCOS, the National Geographic Research Foundation, CARE Archaeological Foundation, MAFCAF Foundation, the Dan David Foundation, The Shelby White and Leon Levy Program for Archaeological Publications and Sandy and Joseph Lepelstat for their financial support of the research described here. The Israel Antiquities Authority, the Israel Prehistoric Society and Haifa University are acknowledged for their financial and administrative support of the underwater excavations and H. Rosenstein and Fantasea for providing photographic equipment. We also wish to express our appreciation to the divers and archaeologists who participated in the underwater excavations, to the many researchers who subsequently contributed to the study of the finds, to S. Ben-Yehuda and B. Galili for producing the drawings, to J. Galili and I. Grinberg for taking the underwater photographs, to M. Rasovsky (treatment of organic material) and to D. Segal, I. Carmi and E. Boaretto of the Weizmann Institute (radiocarbon dating). Special thanks are due to Geoff Bailey for discussion of the factors contributing to site preservation and discovery and for his useful comments and comprehensive editing of the manuscript.

\section{References}

Banning EB (1995) Herders or homesteaders? A Neolithic farm in Wadi Ziqlab, Jordan. Bibl Archaeol 58:2-13

Bar-Yosef O, Garfinkel Y (2008) The prehistory of Israel. Human cultures before writing. (In Hebrew)

Bar-Yosef Mayer DE, Vandermeersch B, Bar-Yosef O (2009) Shells and ochre in Middle Paleolithic Qafzeh cave, Israel: indications for modern behavior. J Human Evol 56:307-314

Barkai R (2011) The evolution of Neolithic and Chalcolithic woodworking tools and the intensification of human production: Axes, adzes, and chisels from the southern Levant. In: Davis V, Edmonds M (eds) Stone axe studies III. Oxbow Books, Oxford, pp 39-54

Barkai R, Galili E (2004) The PPNC bifacial tool industry from the submerged site of Atlit-Yam, Israel. Eurasian Prehist 1:139-162

Barkai R, Gopher A (2012) Flint assemblages from Nahal Zehora II: Techno-typological changes during the PN. In: Gopher A (ed) Village communities of the
Pottery Neolithic Period in the Menashe Hills, Israel. Archaeological investigations at the sites of Nahal Zehora, vol II. Emery and Claire Yass Publications in Archaeology, Institute of Archaeology, Tel Aviv University, Tel Aviv, pp 757-869

Benjamin J, Rovere A, Fontana A, Furlani S, Vacchi M, Inglis RH, Galili E, Antonioli F, Sivan D, Miko S, Mourtzas N, Felia I, Meredith-Williams M, GoodmanTchernov B, Kolaiti E, Anzidei M, Gehrels R (2017) Late quaternary sea-level changes and early human societies in the central and eastern Mediterranean Basin: an interdisciplinary review. Quater Int 449:29-57

Bronk Ramsey C (2017) Methods for summarizing radiocarbon datasets. Radiocarbon 59(2):1809-1833

Butzer KW (1996) Ecology in the long view: settlement histories, agrosystemic strategies, and ecological performance. J Field Archaeol 23:141-150

Donoghue HD, Hershkovitz I, Minnikin DE, Besra GS, Lee OYC, Galili E, Greenblatt CL, Lemma E, Spigelman M, Kahila Bar-Gal G (2009) Biomolecular archaeology of ancient tuberculosis: Response to "Deficiencies and challenges in the study of ancient tuberculosis DNA" by Wilbur et al. (2009). J Archaeol Sci 36:2792-2804

Dunand M (1973) Fouilles de Byblos V: L'architecture, les tombes, le matériel domestique: des origines néolithiques à l'avènement urbain. Paul Guethner, Paris

Enzel Y, Bar-Yosef O (2017) Quaternary of the Levant. Cambridge University Press, Cambridge

Eshed V, Galili E (2011) Palaeodemography of southern Levantine Pre-Pottery Neolithic populations: regional and temporal perspectives. In: Pinhasi R, Stock J (eds) Human bioarchaeology of the transition to agriculture. Wiley, Chichester, pp 403-428

Eshed V, Gopher A, Gage TB, Hershkovitz I (2004) Has the transition to agriculture reshaped the demographic structure of prehistoric populations? New evidence from the Levant. Am J Phys Anthropol 124:315-329

Eshed V, Gopher A, Pinhasi R, Hershkovitz I (2010) Paleopathology and the origin of agriculture in the Levant. Am J Phys Anthropol 143:121-133

Galili E (1981) Underwater erosion processes, unpublished field study report submitted to M Inbar, Department of Geography, The University of Haifa, 69 pp. (In Hebrew)

Galili E (1985) Clay exposures and archaeological finds on the sea bottom, between Haifa and Atlit. Unpublished MA Thesis, Dept. of Maritime Civilizations, University of Haifa. (In Hebrew)

Galili E (2004) Submerged settlements of the ninth to seventh millennia BP off the Carmel Coast. Unpublished $\mathrm{PhD}$ thesis, University of Tel Aviv. (In Hebrew, English abstract)

Galili E (2017) Book review: prehistoric archaeology on the continental shelf. A global review. J Island Coastal Archaeol 12(1):147-149. https://doi.org/10.1080/155 64894.2016.1225323

Galili E, Nir Y (1993) The submerged Pre-Pottery Neolithic water well of Atlit-Yam, Northern Israel, and 
its palaeoenvironmental implications. The Holocene 3:265-270

Galili E, Rosen B (2007) Artifacts made of plant material, Kfar-Samir, submerged Neolithic site off the south coast of Haifa. Hadashot Arkheologiyot 119

Galili E, Rosen B (2011a) Submerged Neolithic settlements off the Mediterranean coast of Israel. In: Benjamin J, Bonsall C, Pickard C, Fischer A (eds) Submerged prehistory. Oxbow, Oxford, pp 272-286

Galili E, Rosen B (2011b) Submerged Neolithic settlements off the Mediterranean Carmel coast of Israel and water mining in the Southern Levant. Neo-Lithics 2(10):47-52

Galili E, Rosen B (2013) Atlit Yam- preliminary report. Hadashot Arkheologiyot 125

Galili E, Schick T (1990) Basketry and a wooden bowl from the Pottery Neolithic submerged site of Kefar Samir. Mitekufat Haeven. J Israel Prehist Soc 23:6568 (in Hebrew), 142-151 (in English)

Galili E, Sharvit J (1994-5) Evidence of olive oil production from the submerged site at Kfar Samir, Israel. Mitekufat Haeven. J Israel Prehist Soc 26:122-133

Galili E, Weinstein-Evron M (1985) Prehistory and paleoenvironments of submerged sites along the Carmel coast of Israel. Paléorient 11:37-52

Galili E, Zviely D (2018) Geo-archaeological markers reveal magnitude and rates of Israeli coastal cliff erosion and retreat. J Coast Conserv. https://doi. org/10.1007/s11852-018-0644-7

Galili E, Weinstein-Evron M, Ronen A (1988) Holocene sea-level changes based on submerged archaeological sites off the northern Carmel coast in Israel. Quater Res 29:36-42

Galili E, Weinstein-Evron M, Zohary D (1989) Appearance of olives in submerged Neolithic sites along the Carmel coast. Mitekufat Haeven. J Israel Prehist Soc 22:95-97

Galili E, Weinstein-Evron M, Hershkovitz I, Gopher A, Kislev M, Lernau O, Horwitz LK, Lernau H (1993) Atlit-Yam: a prehistoric site on the sea floor off the Israeli coast. J Field Archaeol 20:133-156

Galili E, Stanley DJ, Sharvit J, Weinstein-Evron M (1997) Evidence for earliest olive-oil production in submerged settlements off the Carmel coast, Israel. J Archaeol Sci 24:1141-1150

Galili E, Rosen B, Gopher A, Horwitz LK (2002) The emergence and dispersion of the Eastern Mediterranean fishing village: evidence from submerged Neolithic settlements off the Carmel coast, Israel. J Medit Archaeol 15:167-198

Galili E, Lernau O, Zohar I (2004) Fishing and marine adaptations at Atlit-Yam, a submerged Neolithic village off the Carmel coast, Israel. Atiqot 48:1-34

Galili E, Zviely D, Weinstein-Evron M (2005a) Holocene sea-level changes and landscape evolution on the Northern Carmel coast (Israel). Mediterranée 1(2):1-8

Galili E, Eshed V, Gopher A, Hershkovitz I (2005b) Burial practices at the submerged PPNC site of Atlit-Yam, northern Coast of Israel: what do they tell us about the final phase of the Pre-Pottery Neolithic Culture? Bull Am School Orient Res 339:1-19

Galili E Rosen B, Boaretto E (2007) Haifa, Kafr Samir. Hadashot Arkheologiyot 119. http:// www.hadashot-esi.org.il/Report_Detail_Eng. aspx?id=552\&mag_id=112

Galili E, Horwitz LK, Hershkovitz I, Eshed V, Salamon A, Zviely D, Weinstein-Evron M, Greenfield $\mathrm{H}$ (2008) Comment on "Holocene tsunamis from Mount Etna and the fate of Israeli Neolithic communities" by Maria Teresa Pareschi, Enzo Boschi, and Massimiliano Favalli. Geophy Res Lett 35:L08311. https://doi.org/10.1029/2008GL033445

Galili E, Eshed V, Rosen B, Kislev ME, Simchoni O, Hershkovitz I, Gopher A (2009) Evidence for a separate burial ground at the submerged Pottery Neolithic site of Neve-Yam, Israel. Paléorient 35(1):31-46

Galili E, Zemer A, Rosen B (2013) Ancient fishing gear and associated artifacts from underwater explorations in Israel - a comparative study. Archaeofauna 22:145-166

Galili E, Cvikel D, Benjamin J, McCarthy J (2016a) Haifa, Kefar Samir (Dado beach). HA-Excavations and Surveys in Israel 128

Galili E, Rosen B, Orrelle E, Yaroshevich A, Horwitz LK (2016b) Symbolic artefacts from the submerged Neolithic village of Neve-Yam and contemporaneous Israeli sites as fossil directeur for the Wadi Rabah culture. Israel Explor J 66(2):129-150

Galili E Eshed V Rosen B, Horwitz LK (2016c) NeveYam, Temanun Island. Hadashot Arkheologiyot 128. http://www.hadashot-esi.org.il/Report_Detail_Eng. aspx?id=25124

Galili E, Nir Y, Vachtman D, Mart Y (2017a) Physical characteristics of the continental shelves of the East Mediterranean Basin, submerged settlements and landscapes - actual finds and potential discoveries. In: Flemming NC, Harff J, Moura D, Burgess A, Bailey GN (eds) Submerged landscapes of the European continental shelf: quaternary paleoenvironments. Wiley, Chichester, pp 377-403

Galili E, Benjamin J, Hershkovitz I, Weinstein-Evron M, Zohar I, Eshed V, Cvikel D, Melamed J, Kahanov Y, Bergeron J, Ruggles C, Ronen A, Horwitz LK (2017b) Atlit-Yam: A unique 9000 year old village submerged off the Carmel coast, Israel - the SPLASHCOS field school (2011). In: Bailey GN, Harff J, Sakellariou D (eds) Under the sea: archaeology and palaeolandscapes of the continental shelf. Springer, Cham, pp 85-102

Galili E, Horwitz LK, Rosen B, Eshed V (2017c) Submerged pottery neolithic settlements off the Mediterranean coast of Israel: subsistence, material culture and the development of separate burial grounds. In: Bailey GN, Harff J, Sakellariou D (eds) Under the sea: archaeology and palaeolandscapes of the continental shelf. Springer, Cham, pp 105-130

Galili E, Benjamin J, Hershkovitz I, Weinstein-Evron M, Zohar I, Eshed V, Cvikel D, Melamed J, Kahanov Y, Bergeron J, Ruggles C, Ronen A, Horwitz LK (2017d) Atlit-Yam: a unique 9000-year-old prehistoric vil- 
lage submerged off the Carmel coast, Israel -The SPLASHCOS Field School 2011. In: Bailey GN, Harff J, Sakellariou D (eds) Under the sea: archaeology and palaeolandscapes of the continental shelf. Springer, Cham, pp 85-102

Galili E, Ronen A, Mienis HK, Horwitz LK (2017e) Beach deposits containing Middle Paleolithic archaeological remains from northern Israel. Quater Int 464(Part A):43-57

Galili E, Cvikel D, Benjamin J, Langgut D, McCarthy J, Cavanagh M, Sapir Y, Weinstein-Evron M, Chaim S, Rosen B, Kolska Horwitz L (2018) The archaeology and paleoenvironment of the submerged Pottery Neolithic settlement of Kfar Samir. Paleorient 44(2):113-132

Galili E, Kolska Horwitz L, Rosen B (2019a) The Israeli model for the detection, excavation and research of submerged prehistory. TINA Maritime Archaeological Periodical, Periodical Publications of the Turkish Archaeological Foundations, pp 31-69

Galili E, Benjamin J, Eshed V, Rosen B, McCarthy J, Kolska Horwitz L, Biehl PF (2019b) A submerged 7000-year-old village and seawall demonstrate earliest known coastal defence against sea-level rise. PLOS ONE 14(12):e0222560

Garrod DAE, Bate DMA (1937) The stone age of Mount Carmel: excavations at the Wady El-Mughara, vol I. Clarendon Press, Oxford

Garfinkel Y (1993) The Yarmukian culture in Israel. Paléorient 19(1):115-134

Garfinkel Y (1999) Neolithic and Chalcolithic pottery of the southern Levant. Qedem 39. Institute of Archaeology, Hebrew University, Jerusalem

Garfinkel Y, Dag D (eds) (2008) Neolithic Ashkelon. Qedem 47. Institute of Archaeology, Hebrew University, Jerusalem

Gopher A (1995) Early pottery-bearing groups in Israel the Pottery Neolithic period. In: Levy TE (ed) The archaeology of society in the Holy Land. Facts on File, New York, pp 205-225

Gopher A (2012) The pottery neolithic in the Southern Levant - a second Neolithic revolution. In: Gopher A (ed) Village communities of the Pottery Neolithic Period in the Menashe Hills, Israel. Archaeological investigations at the sites of Nahal Zehora, vol II. Emery and Claire Yass Publications in Archaeology, Institute of Archaeology, Tel Aviv University, Tel Aviv, pp 1525-1575

Gopher A, Gophna R (1993) Cultures of the eighth and seventh millennia BP in the southern Levant: a review for the 1990's. J World Prehist 7:297-353

Greenfield H, Galili E, Horwitz LK (2006) The butchered bones from Newe Yam. Mitekufat Haeven. J Israel Prehist Soc 36:173-200

Greenfield H, Cheney T, Galili E (2013) A taphonomic and technological analysis of the butchered animal bone remains from Atlit Yam, a submerged PPNC site off the coast of Israel. Poster presented at 11th Meeting of Archaeozoology of South West Asia (ASWA), June 23rd-28th, Haifa
Hartmann-Shenkman A, Kislev ME, Galili E, Weiss EA (2015) Invading a new niche: obligatory weeds at Neolithic Atlit-Yam, Israel. Veg Hist Archaeobot 24(1):9-18. https://doi.org/10.1007/ s00334-014-0498-3

Helmer D (1989) Le dévelopment de la domestication au Proche-Orient de 9500 à 7500 BP: les nouvelles données d'El Kowm et de Ras Shamra. Paléorient 15:111-121

Hershkovitz I, Galili E (1990) 8000-year-old human remains on the sea floor near Atlit, Israel. Human Evol 5:319-358

Hershkovitz I, Bing B, Speirs M, Galili E, Kislev M, Edelson G, Hershkovitz A (1991) Possible congenital anaemia in prehistoric coastal inhabitants of Israel. Am J Phys Anthropol 85:7-13

Hershkovitz I, Donoghue H, Minnikin D, Besra G, Lee O, Gernaey AM, Galili E, Eshed V, Greenblatt C, Lemma E, Bar-Gal GK, Spiegelman M (2008) Detection and molecular characteristics of 9000-yearold Mycobacterium tuberculosis from a Neolithic settlement in the Eastern Mediterranean. PLoS ONE 3(10):e3426. https://doi.org/10.1371/journal. pone. 0003426

Hershkovitz I, Weber GW, Quam R, Duval M, Grün R et al (2018) The earliest modern humans outside Africa. Science 359(6374):456-459. https://doi.org/10.1126/ science.aap8369

Hesse B, Rookis D (2008) The mammal bones. In: Garfinkel Y, Dag D (eds) Neolithic Ashkelon. Qedem 47, pp 251-254

Horwitz LK, Ducos P (2005) Counting cattle: trends in Neolithic Bos frequencies from the southern Levant. Revue de Paleobiologie 10:209-224

Horwitz LK, Tchernov E (1987) Animal exploitation at the submerged PPNB site of Atlit. Mitekufat Haeven. J Israel Prehist Society 20:72-78

Horwitz LK, Galili E, Sharvit J, Lernau O (2002) Fauna from five submerged Pottery Neolithic sites off the Carmel coast. Mitekufat Haeven. J Israel Prehist Soc 32:147-174

Horwitz K, Lernau O, Galili E (2006) Fauna from the Pottery Neolithic site of Neve-Yam. Mitekufat Haeven. J Israel Prehist Soc 36:139-171

Kafri U, Arad A (1978) Paleohydrology and migration of the groundwater divide in regions of tectonic instability in Israel. Geol Soc Am Bull 89:1723-1732

Kislev ME, Hartmann A, Galili E (2004) Archaeobotanical and archaeoentomological evidence from a well at Atlit-Yam indicates colder, more humid climate on the Israeli coast during the PPNC, farming, and social complexity in the Pre-Pottery Neolithic of the southern Levant: a review and synthesis. J World Prehist 16:361-440

Learmouth ATA (1977) Malaria. In: Howe GM (ed) A world geography of human diseases. Academic Press, London, pp 61-108

Lernau O (2008) The fish bones. In: Garfinkel Y, Dag D (eds) Neolithic Ashkelon. Qedem 47, pp 263-268 
Mauz B, Hijma MP, Amorosi A, Porat N, Galili E, Bloomindale J (2013) Aeolian beach ridges and their significance for climate and sea level: Concept and insight from the Levant coast (East Mediterranean). Earth Sci Rev 121:31-54

Milevski Y, Getzov N, Galili E, Horwitz LK (2016) Some iconographic motifs from the 6th-5th millennia BC in the Levant and Mesopotamia: clues for cultural connections. Paleorient 42:135-149

Nir Y, Eldar-Nir I (1986) Eustatic sea level changes and their possible influence on the Nile littoral-cell beaches. In: Raukas A (ed) Evolution and dynamics of seacoasts in conditions of relative sea level oscillation: excursion guides and abstracts, International Symposium, Aug. 20-26, 1986. International Symposium. Academy of Sciences of the Estonian SSR, Institute of Geology, Tallinn, p 63

Nir Y, Eldar-Nir I (1987) Ancient wells and their geoarchaeological significance in detecting tectonics of the Israel Mediterranean coastline region. Geology 15:3-6

Nir Y, Eldar-Nir I (1988) Construction techniques and building materials used in ancient water wells along the coastal plain of Israel. In: Marinos PG, Koukis GC (eds) Engineering geology of ancient works, monuments and historical sites. Balkema, Rotterdam, pp 1765-1771

Olami Y (1984) Prehistoric carmel. Israel Exploration Society, Jerusalem

Pareschi MT, Boschi E, Favalli M (2006) Lost tsunami. Geophys Res Lett 33:L22608. https://doi. org/10.1029/2006GL027790

Pareschi MT, Boschi E, Favalli M (2007) Holocene tsunamis from Mount Etna and the fate of Israeli Neolithic communities. Geophys Res Lett 34:L16317

Perrot I, Gopher A (1996) A Late Neolithic site near Ashkelon. Israel Explor J 46:145-166

Porat N, Jain M, Ronen A, Horwitz LK (2018) A contribution to late Middle Paleolithic chronology of the Levant: New luminescence ages for the Atlit Railway Bridge site, coastal plain, Israel. Quater Int 464(Part A):32-42

Reimer PJ, Bard E, Bayliss A, Beck JW et al (2013) IntCal13 and marine13 radiocarbon age calibration curves 0-50,000 years cal BP. Radiocarbon 55(4):18691887. https://doi.org/10.2458/azu_js_rc.55.16947

Rollefson GO (1990) Neolithic chipped stone technology at 'Ain Gazal, Jordan: the status of the PPNC phase. Paléorient 16:119-124

Rollefson G, Simmons A, Kafafi Z (1992) Neolithic cultures at Ain Ghazal, Jordan. J Field Archaeol 19:443-470

Ron H, Porat N, Ronen A, Tchernov E, Horwitz LK (2003) Magnetostratigraphy of the Evron member implications for the age of the Middle Acheulian site of Evron quarry. J Human Evol 44:633-639

Ronen A (1977) Mousterian sites in red loam in the Carmel coastal plain. Eretz Israel (Moshe Stekelis) 13:183-190
Ronen A, Chernikov I (2010) The Mousterian of the red loam on the Carmel coast (Israel). Acta Universitatis Wratislaviensis No 3207. Studia Archeologiczne 41:1-22

Ronen A, Kaufman D (1976) Epi-Palaeolithic sites near Nahal Hadera, Central Coastal Plain of Israel. Tel Aviv 3(1): 16-30

Ronen A, Olami Y (1978) Atlit map. Archaeological Survey of Israel, Jerusalem

Ronen A, Kaufman D, Gophna R, Bakler N, Smith P, Amiel A (1975) The Epipalaeolithic site of Hefziba, central coastal plain of Israel. Quärtar 26:54-72

Ronen A, Neber A, Mienis H, Horwitz LK, Frumkin A, Boenigk W, Galili E (2008a) A Mousterian occupation on an OIS 5e shore near the Mount Carmel Caves, Israel. In: Sulgostowska Z, Tomaszewski AJ (eds) Man, millennia, environment. Studies in honour of Romuald Schild. Institute of Archaeology and Ethnology, Polish Academy of Sciences, Warszawa, pp 197-205

Ronen A, Horwitz LK, Mienis H, Galili E, Zviely D (2008b) Mousterian sites on the Carmel Coast. Kadmoniot 134:75-81 (In Hebrew)

Segal D, Carmi I (1996) Rehovot Radiocarbon Date List V.'Atiqot, pp 79-106

Shea JJ (2003) The middle Paleolithic of the East Mediterranean Levant. J World Prehist 17:313-394

Simmons AH (2007) The Neolithic revolution in the near east: transforming the human landscape. University of Arizona Press, Tucson, AZ

Sivan D, Widowinski S, Lambeck K, Galili E, Raban A (1999) Changes in sea-level along the Israeli coast during the Holocene - combination of eustatic, isostatic and tectonic factors. Archaeol Nat Sci, Bulletin no. 7, April 1999, pp 80-84. (In Hebrew)

Smith P, Horwitz LK (2007) Ancestors and inheritors: a bio-cultural perspective of the transition to agropastoralism in the Southern Levant. In: Cohen MN, Crane-Kramer GMM (eds) Ancient health. Skeletal indicators of agricultural and economic intensification. University Press of Florida, Gainesville, pp 207-222

Sneh Y, Klein M (1984) Holocene sea level changes of the coast of Dor, southeast Mediterranean. Science 226:831-832

Stekelis M (1972) The Yarmukian Culture of the Neolithic Period. Magnes Press, Jerusalem

Stuiver M, Reimer PJ (1993) Extended C-14 data-base and revised Calib 3.0 C-14 age calibration program. Radiocarbon 35(1):215-230

Van Zeist W, Bakker-Heeres JAH (1984) Archaeobotanical studies in the Levant 2: Neolithic and Halaf levels at Ras Shamra. Palaeohistoria 26:151-170

Weinstein-Evron M (1994) Biases in archaeological pollen assemblages: case studies from Israel. AASP Contrib Ser 29:193-205

Weinstein-Evron M (2015) The case of Mount Carmel: the Levant and human evolution, future research in the framework of World Heritage. In: Sanz N (ed) Human 
origin sites and the World Heritage Convention in Eurasia, HEADS 4, vol 1. UNESCO, Paris, pp 72-92 World Health Organization (WHO) (2017) World Malaria Report 2017. Geneva, Switzerland. http://www.who. int/malaria/publications/world-malaria-report-2017/ en/

Wreschner EE (1977a) Neve-Yam, a submerged Late Neolithic settlement near Mount Carmel. Eretz Israel 13:260-271

Wreschner EE (1977b) Sea level changes and settlement location in the coastal plain of Israel during the Holocene. Eretz Israel 13:277-282

Wreschner EE (1983) The submerged Neolithic village 'Neve-Yam' on the Israeli Mediterranean coast. In: Masters PM, Flemming NC (eds) Quaternary coastlines and marine archaeology. Academic Press, London, pp 325-333

Yerkes RW, Galili E, Barkai R (2014) Activities at final Pre-Pottery Neolithic (PPNC) fishing village revealed through microwear analysis of bifacial flint tools from the submerged Atlit-Yam site, Israel. J Archaeol Sci 4:120-128
Zeder MA (2011) The origins of agriculture in the Near East: New data, new ideas. Curr Anthropol 52(S4):S211-S235

Zohar I, Dayan T, Spanier E, Galili E, Lernau O (1994) Exploitation of gray triggerfish (Balistes carolinensis) by the prehistoric inhabitants of Atlit-Yam, Israel: a preliminary report. In: Van Neer W (ed) Fish exploitation in the past. Proceedings of the 7th Meeting of the ICAZ Fish Remains Working Group. Annalen Zoologische Wetenschapen; vol. 274. Koninklijk Museum voor Midden-Africa, Tervuren, België, pp 231-238

Zohar I, Dayan T, Galili E, Spanier E (2001) Fish processing during the early Holocene: a taphonomic study. J Archaeol Sci 28:1041-1053

Zohary D, Hopf M (2000) Domestication of plants in the Old World, 3rd edn. Oxford University Press, Oxford

Zviely D, Kit E, Klein M (2007) Longshore sand transport estimates along the Mediterranean coast of Israel in the Holocene. Mar Geol 238:61-73

Open Access This chapter is licensed under the terms of the Creative Commons Attribution 4.0 International License (http://creativecommons.org/licenses/by/4.0/), which permits use, sharing, adaptation, distribution and reproduction in any medium or format, as long as you give appropriate credit to the original author(s) and the source, provide a link to the Creative Commons licence and indicate if changes were made.

The images or other third party material in this chapter are included in the chapter's Creative Commons licence, unless indicated otherwise in a credit line to the material. If material is not included in the chapter's Creative Commons licence and your intended use is not permitted by statutory regulation or exceeds the permitted use, you will need to obtain permission directly from the copyright holder. 